Research Article

\title{
Intercropping and Nitrogen Fertilization Altered the Patterns of Leaf Senescence in Sorghum
}

\author{
Peter E. Moi $\mathbb{D}^{D}$, Onesmus M. Kitonyo $\mathbb{D}^{D}$, George N. Chemining'wa ${ }^{\mathbb{D}}$, and Josiah M. Kinama \\ Department of Plant Science and Crop Protection, University of Nairobi, P.O. Box 3019700100 GPO, Nairobi, Kenya \\ Correspondence should be addressed to Peter E. Moi; moipeter799@gmail.com
}

Received 4 June 2021; Revised 18 September 2021; Accepted 23 October 2021; Published 12 November 2021

Academic Editor: David Clay

Copyright (C) 2021 Peter E. Moi et al. This is an open access article distributed under the Creative Commons Attribution License, which permits unrestricted use, distribution, and reproduction in any medium, provided the original work is properly cited.

\begin{abstract}
Leaf senescence regulates grain yield. However, the modulation of leaf senescence in sorghum under legume-based intercrop systems and nitrogen $(\mathrm{N})$ fertilization is not known. The objective of the study was to investigate the effect of intercropping two sorghum (Gadam and Serena) and cowpea (K80, M66) varieties and sole cropping systems and different fertilizer N rates (0, 40, and $80 \mathrm{~kg} \cdot \mathrm{N} \cdot \mathrm{ha}^{-1}$ ) on the time course of postflowering sorghum leaf senescence and understand how senescence modulates grain yield. The experiment was laid out in a randomized complete block design with a split-plot arrangement with three replications. Leaf senescence was assessed from flowering to maturity at (a) whole-plant level by the visual scoring of green leaves and (b) flag leaf scale by measuring leaf greenness with a SPAD 502 chlorophyll meter. A logistic function in SigmaPlot was fitted to estimate four traits of leaf senescence, including minimum and maximum SPAD (SPADmin, SPADmax), time to loss of 50\% SPADmax (EC50), and the rate of senescence. Irrespective of the cowpea variety, intercropping reduced sorghum grain yield by $50 \%$. The addition of $\mathrm{N}$ increased yield by $27 \%$ but no effect was detected between 40 and $80 \mathrm{~kg} \cdot \mathrm{N} \mathrm{ha}^{-1}$. Intercropping delayed leaf senescence at the whole plant by 0.2 leaves plant ${ }^{-1}$ day $^{-1}$ but reduced SPADmax of the flag by 8 SPAD units and rate of senescence by 4 SPAD units day ${ }^{-1}$ compared with sole crop system. Fertilizer $N$ delayed leaf senescence $(P \leq 0.05)$ at whole-plant and flag leaf scales. Cropping System $\times$ nitrogen modulated senescence at whole-plant and flag leaf scales and sorghum grain yield but marginally influenced other traits. While EC50 did not correlate with grain yield, faster rates of senescence and leaf greenness were associated with high yield under the sole crop system. Overall, $\mathrm{N}$ was the main factor in driving sorghum leaf senescence while the intercropping effect on senescence was nonfunctional. Effects of competition in sorghum-legume intercropping and source-sink relationships on the patterns of leaf senescence deserve further investigation.
\end{abstract}

\section{Introduction}

Intercropping and best management practices of fertilizer nitrogen can increase crop yield in dryland environments $[1,2]$. However, previous studies on intercropping and nitrogen use only emphasized crop growth and yield with limited information on leaf senescence. Senescence is closely associated with the photosynthetic capacity and chlorophyll content of the leaf, and it increases toward crop maturity due to declining trends of photosynthesis and chlorophyll contents of the leaf after flowering [3]. In cereal crops, leaf senescence patterns profoundly impact grain yield and quality by regulating source-sink relationships for nutrient demand $[3,4]$. Five traits are used to describe the leaf senescence patterns, and they include the maximum and minimum leaf greenness, the start of senescence, time to loss of $50 \%$ of peak leaf greenness, and the rate of senescence $[5,6]$. Prolonged leaf greenness has been correlated with higher grain yield in sorghum (Sorghum bicolor (L.) Moench) [5, 7], wheat (Triticum L.) [8], and maize (Zea mays L.) [6]. In addition, a delayed but rapid rate of leaf senescence has been shown to increase wheat grain mass [9]. Manipulation of these traits of senescence could potentially increase grain yield of sorghum in drylands, where both rainfall amount and frequency decline as crops mature [10].

Cereal-legume intercropping is a sustainable agricultural practice of simultaneously growing at least two crops on the same land [2]. The principle objective of intercropping is to increase crop productivity from a unit area where available growth resources are efficiently utilized [11]. In comparison 
with sole crop systems, intercropping improves crop diversification, increases crop yield and stability, especially under low-input conditions, and improves soil fertility and conservation, as well as weed control [12-14]. Further, intercropping and other practices such as mulching have been reported to regulate senescence through increased net photosynthetic duration and prolonged leaf greenness in proso millet $[3,15]$.

In spite of the wide adoption of intercropping in tropical environments, the practice has some limitations. For instance, an earlier study established that sorghum and cowpea grain yield grown in sole exceeded yields of counterparts in an intercrop system [16]. Additionally, a study on sorghumcowpea intercropping reported that sole sorghum exceeded $31 \%$ of the intercropped sorghum yield [2]. This is because of interspecific competition for resources like soil nutrients, sunlight, and water in the intercropped sorghum [1]. Further, cereals like sorghum are nutrient-exhaustive crops, and the legume may not meet all the $\mathrm{N}$ requirement of cereal without external fertilizer $\mathrm{N}$ supply [16]. However, while the influence of intercropping on sorghum growth and yield has been reported in previous studies, intercropping influence on senescence traits in cereal like sorghum has not been widely understood; hence, establishing intercropping effect on sorghum leaf senescence could help correlate with grain yield.

Nitrogen regulates the patterns of senescence in many crops, including sorghum [17]. This is attributed to sourcesink relations which impacts $\mathrm{N}$ remobilization from senescing leaves to the reproductive structures, thus, impacting leaf senescence [4]. Under moisture stress conditions, prolongation of leaf greenness has been demonstrated to improve grain yield, stem mass, and lodging resistance [5]. In cereals like maize, the maximum leaf greenness before flowering has been correlated with grain yield and yield traits under normal conditions [6]; however, evidence of how nitrogen fertilizer influence leaf senescence in sorghum under intercrop system remains limited. The flag leaf in cereal plays a pivotal function in the provision of photosynthates during grain filling in cereal [18-20]. A decline in the photosynthetic rate of the flag leaf has been reported which leads to a significant yield decrease in monocarpic crops such as rice [20], wheat [21], and barley [22], irrespective of the environment, normal or dryland environment [23]. However, there exists limited evidence on the impact of $\mathrm{N}$ on the pattern of sorghum leaf senescence at flag leaf and whole-plant scale and its association with grain yield.

Intercropping and nitrogen addition have been shown to regulate the patterns of leaf senescence in many crops, for example, in proso millet $[3,15]$, Maize $[5,6,24]$, sorghum [5], and wheat [7], but the responsible mechanisms are only partially understood. Therefore, understanding physiological processes such as senescence and their association with grain yield would help in the sorghum yield improvement process. Thus, the objective of the study was to investigate the time course of postflowering leaf senescence of sorghum under intercrop and sole cropping systems and different fertilizer $\mathrm{N}$ rates and understand how senescence modulates grain yield. This study hypothesized that intercropping sorghum with cowpea and higher fertilizer $\mathrm{N}$ rates could delay leaf senescence and increase the grain yield of sorghum.

\section{Materials and Methods}

2.1. Sites Description. Two field experiments were simultaneously conducted under rainfed conditions at the Kenya Agricultural and Livestock Research Organization (KALRO) stations in Katumani and Igoji during the 2018/2019 short rains. Katumani is located $01^{\circ} 35^{\prime} \mathrm{S}, 37^{\circ} 14^{\prime} \mathrm{E}$ and 1575 meters above sea level (masl) while Igoji $0^{\circ} 11^{\prime} 13^{\prime \prime} \mathrm{S}, 37^{\circ} 40^{\prime} 10^{\prime \prime} \mathrm{E}$ and 1770 masl [25]. Katumani is in upper mid-land zone four (UM4) with a mean annual temperature of $19^{\circ} \mathrm{C}$ [25]. The mean annual rainfall in this site is $655 \mathrm{~mm}$. Soils of Katumani are ferral chromic luvisols [26]. Igoji is in upper midland zone two (UM2) and has a mean annual temperature of $20^{\circ} \mathrm{C}$ [25]. The mean annual rainfall is $1580 \mathrm{~mm}$, and the soils of Igoji are deep well-drained volcanic soil [25]. Rainfall distribution in both sites occurs in two seasons where long rains fall between March and July while short rains are received between October and December [10]. In Katumani, the short rains season is drier $(288 \mathrm{~mm})$ compared with Igoji which receives $370 \mathrm{~mm}$.

Daily minimum and maximum rainfall and temperature data from the onset of the flowering of sorghum to physiological maturity were collected from weather stations in both sites. Monthly means were computed for both parameters.

Prior to sowing the crops, soils were sampled at $0-30 \mathrm{~cm}$ depth and analyzed. A Mehlich double acid method was used to analyze the soils for $\mathrm{P}, \mathrm{K}, \mathrm{Na}, \mathrm{Ca}, \mathrm{Mg}, \mathrm{Mn}, \mathrm{Fe}, \mathrm{Zn}$, and $\mathrm{Cu}$. The total organic carbon (C) \% was analyzed using the colorimetric method while the total nitrogen $(\mathrm{N}) \%$ was determined using the Kjeldahl method [27]. A digital $\mathrm{pH}$ meter (Oakton Instruments (888-462-5866) https://www. 4oakton.com/) was used to measure the soil $\mathrm{pH}$ in a ratio of $1: 1$ soil-water suspension (w/v) [27]. The ammonium acetate method was used to analyze cation exchange capacity (CEC) [27].

2.2. Treatments and Experiment Design. In both sites, the effects of cropping system (intercrop and sole) with two varieties of sorghum and cowpea and three rates of fertilizer nitrogen $\left(0,40\right.$, and $\left.80 \mathrm{~kg} \cdot \mathrm{N} \cdot \mathrm{ha}^{-1}\right)$ were evaluated. In the intercrop system, a row of cowpea was sown between two rows of sorghum. Locally adapted Gadam and Serena sorghum varieties were used as test crops while cowpea varieties comprised Machakos 66 (M66) and Katumani 80 (K80). The yield potential of Gadam and Serena is 4.5 and $2.3 \mathrm{t} \cdot \mathrm{ha}^{-1}$, respectively, while that of M66 and K80 is $1.8 \mathrm{t} \cdot \mathrm{ha}^{-1}$ [28]. The seed for both crops was sourced from Katumani Seed Unit at the KALRO research station.

Fertilizer $\mathrm{N}$ was supplied from urea $(46 \% \mathrm{~N})$ and applied to the sidebands on the planting rows of both sorghum and cowpea in fractions of a third ( ${ }^{1} \tilde{\mathrm{o}} \tilde{\mathrm{o}} / 3$ ) at sowing and twothirds $\left({ }^{2} \tilde{\text { õo }} / 3\right.$ ) top-dressed at tillering stage of sorghum 
growth. All treatment plots received $60 \mathrm{~kg} \cdot \mathrm{P} \cdot \mathrm{ha}^{-1}$ of basal fertilizer in the form of triple superphosphate (0-45-0) that was applied to the sidebands on the planting rows of both crops. The field experiments were laid out in a randomized complete block design (RCBD) with a split-plot arrangement with three replications. Factorial combinations of sorghum-cowpea intercropping or sole crop formed the main plots while $\mathrm{N}$ rate formed the subplots. The main plots measured $24 \mathrm{~m} \times 8 \mathrm{~m}$ and subplots were $12 \mathrm{~m} \times 4 \mathrm{~m}$. The main plots were separated by a $1 \mathrm{~m}$ path and the subplot by a $0.5 \mathrm{~m}$ path while treatment blocks were separated by a $2 \mathrm{~m}$ path.

Primary tillage was done a week prior to the onset of the rains followed by secondary tillage during the 2018/2019 short rains season in both experimental sites. The planting was manually done by placing seeds in holes of $5 \mathrm{~cm}$ deep opened using a machete. Crops were planted at the onset of rains at $10 \mathrm{~kg} \cdot \mathrm{ha}^{-1}$ seed rate for both sorghum and cowpea. In the sole crop system, sorghum was sown $75 \mathrm{~cm}$ between rows and $20 \mathrm{~cm}$ within plants while cowpea was sown $60 \mathrm{~cm}$ between rows and $30 \mathrm{~cm}$ within plants. In the intercrop component, sorghum was sown $90 \mathrm{~cm}$ between rows and a row of cowpea between two rows of sorghum with a spacing of $20 \mathrm{~cm}$ from plant to plant. In both crops, three seeds were planted in each hole and later thinned to one plant per hole to achieve a sorghum density of 6.7 plants $\cdot \mathrm{m}^{-2}$ in the sole crop system and 5.6 plants. $\mathrm{m}^{-2}$ in the intercrop system. Cowpea plant density was 5.6 plants $\mathrm{m}^{-2}$ in the sole crop system and 3.7 plants $\mathrm{m}^{-2}$ in an intercrop system.

Preemergence weed control was done using Roundup ${ }^{\circledR}$ (glyphosate) immediately after sowing. Experiments were kept weed-free through hand weeding. Insect pests, mainly thrips and aphids in cowpea and stem borers in sorghum, were controlled with Thunder ${ }^{\circledR}$ (Imidacloprid $100 \mathrm{~g} / \mathrm{L}+$ Betacyfluthrin $45 \mathrm{~g} / \mathrm{L}$ ) at $120 \mathrm{~mL}$ acre $^{-1}$. Sorghum was guarded against birds feeding on the grains at grain filling until harvesting.

\subsection{Data Collection}

2.3.1. Grain Yield and Yield Traits. Sorghum panicles were harvested using a knife at maturity in a net plot area of $16 \mathrm{~m}^{2}$ and air-dried. Prior to threshing, the sorghum panicle length and width of 10 air-dried panicles plot $^{-1}$ were measured using a tape measure in centimeters and the average value was determined. Further, the weight of the 10 panicles was weighed using a digital weighing scale, and the mean weight was computed in grams. The panicles were then threshed and cleaned, and a moisture meter was used to determine the grain moisture. The grain weight was then adjusted to $12.5 \%$ moisture content similar to Sibhatu and Belete [2]. Thousand sorghum seeds plot $^{-1}$ were counted using a seed counter and weighed in grams.

2.3.2. Measurement of Leaf Senescence. A phenological scale was used to determine sorghum flowering as $50 \%$ shedding of pollen. Similar to Kitonyo et al. [6], assessment of senescence at whole-plant level was scored visually from a few days after flowering through to maturity by recording the number of green leaves plant ${ }^{-1}$ (leaves that presented more than $50 \%$ green leaf area) using a predetermined interval of 10 days. The number of leaves which presented over 50\% green leaf area was recorded at 10, 20, 30, 40, and 50 days after flowering for five plants, and the means were computed. The leaf senescence of the flag leaf of the tagged plants was measured using a SPAD 502 chlorophyll meter [6]. Chlorophyll content of sorghum flag leaf was measured with a predetermined interval of 10 days after flowering to physiological maturity. For each sorghum plant, three SPAD units were collected at different points of the flag leaf at the tip, middle, and bottom, and an average value was determined for each plant and for the whole plot.

2.3.3. Analysis of Leaf Senescence. SPAD data from the measurement of the flag leaf senescence was subjected to a logistic regression function in SigmaPlot version 10.0 (Systat Software, Inc., San Jose California USA, https:// www.systatsoftware.com) to fit the time course of leaf senescence from 10 days of sorghum flowering through to maturity. Similar to Christopher [5] and Kitonyo et al. [6], the function estimated four parameters of leaf senescence, including the peak leaf greenness (SPADmax), time to the loss of $50 \%$ of SPADmax (EC50), and minimum leaf greenness at maturity (SPADmin), while the slope of the curve gave the rate of leaf senescence (RS as SPAD units day $^{-1}$ ) (Equation 1). The logistic function was fitted for each plot and traits of leaf senescence were subjected to analysis of variance.

$$
y=\operatorname{SPAD} \min +\frac{\mathrm{SPADmax}-\mathrm{SPADmin}}{1+(x / \mathrm{EC} 50) \mathrm{RS}} .
$$

2.4. Data Analysis. Data were subjected to analysis of variance by GenStat 14th Edition at a 5\% probability level. All the measured variables' residuals were normally distributed; hence, transformations were not required. Treatment means were compared and separated using the least significant difference (LSD) test at a probability level of 5\% [29]. Relationships between the traits of leaf senescence and grain yield and yield traits were examined by correlation analysis.

\section{Results}

\subsection{Postflowering Weather Conditions and Initial Soil Fertility}

3.1.1. Weather. Weather conditions from the onset of flowering until physiological maturity are shown in Table 1. Data was consistent with the long-term average for both sites, where rainfall tapers and temperatures increase as the crop matures. Despite long-term data showing that Katumani is drier than Igoji, the mean temperatures between the two sites were relatively similar. In addition, rainfall distribution between the two sites varied significantly where Igoji was drier than Katumani a few weeks after flowering to physiological maturity. 
3.1.2. Initial Soil Fertility. Laboratory analysis of the soil samples revealed that total nitrogen $(0.1 \%$ in both sites), organic carbon (Igoji: 0.93\%, Katumani: 0.83\%), and phosphorus (Igoji: 13.33 ppm, Katumani: 18.33 ppm) levels in both sites were low in both sites. The potassium (Igoji: 0.26 me\%, Katumani: $0.91 \mathrm{me} \%$ ), calcium (Igoji: $1.07 \mathrm{me} \%$, Katumani: $2.9 \mathrm{me} \%$ ), and magnesium (Igoji: $2.48 \mathrm{me} \%$, Katumani: $2.35 \mathrm{me} \%$ ) were adequate in both sites. Further, manganese (Igoji: $0.58 \mathrm{me} \%$, Katumani: $0.5 \mathrm{me} \%$ ), copper (Igoji: 0.55 ppm, Katumani: $1.26 \mathrm{ppm}$ ), iron (Igoji: 18.46 ppm, Katumani: 11.77 ppm), zinc (Igoji: 7.08 ppm, Katumani: $1.88 \mathrm{ppm}$ ), and sodium (Igoji: $0.15 \mathrm{me} \%$, Katumani: $0.16 \mathrm{me} \%$ ) were adequate for sorghum and cowpea production. The soil pH was 5.6 in Igoji and 5.9 in Katumani, thus, recommended for sorghum and cowpea production.

\subsection{Grain Yield and Yield Traits}

3.2.1. Grain Yield. Sorghum grain yield was significantly affected by cropping system $(P<0.001)$ in both sites, $\mathrm{N}$ rate in Igoji $(P=0.015)$ and Katumani $(P=0.013)$ and cropping system $x \mathrm{~N}$ rate interactions in Igoji $(P<0.001)$ and Katumani $(P=0.031)$ (Table 2$)$. Under the sole crop system, Gadam sorghum out-yielded Serena by $1.3 \mathrm{t} \cdot \mathrm{ha}^{-1}$ in Igoji but there were no differences in yield between the two varieties in Katumani. However, intercropping significantly reduced the grain yield of both sorghum varieties by about $50 \%$, irrespective of the cowpea variety (Table 2). The addition of fertilizer increased grain yield by at least $27 \%$ in both sites but yield differences between 40 and $80 \mathrm{~kg} \cdot \mathrm{N} \cdot \mathrm{ha}{ }^{-1}$ were marginal under both sole crop and intercrop systems (Table 2). Cropping system $\times N$ rate effect on sorghum grain yield in Igoji revealed that while sorghum grain yield increased with the addition of $\mathrm{N}$ under sole crop system, higher $\mathrm{N}$ rates only marginally increased yield under the intercropping system (Table 2; Figure 1). Sorghum grain yield was a function of SPADmax, SPADmin, and rate of leaf senescence but EC50 was insignificantly correlated with grain yield (Table 3 ).

3.2.2. Yield Traits. In both experimental sites, intercropping reduced the panicle weight of both sorghum varieties by an average of $8 \mathrm{~g}$ (Igoji, $P=0.039$; Katumani, $P=0.044$ ) ( $\mathrm{Ta}-$ ble 2). This trait was not affected by the addition of $\mathrm{N}$ and interactions between the cropping system and $\mathrm{N}$ rate in both sorghum varieties and experimental sites (Table 2). Generally, Gadam seeds were heavier than those of Serena by about $4 \mathrm{~g}$ in both sites (Table 2). In spite of some inconsistent results, intercropping sorghum with either cowpea variety significantly reduced 1000 -seed weight by about $4 \mathrm{~g}$ for both varieties only in the dry environment (Katumani, $P<0.001$ )) but intercropping only affected Serena sorghum variety in the wetter environment (Igoji, $P=0.002$ ) (Table 2). The addition of $\mathrm{N}$ and the interaction between the cropping system and $\mathrm{N}$ rate did not significantly affect 1000 -seed weight in both sites (Table 2). Panicle width and length differed between the two sorghum varieties while the cropping system impacted the two traits differently across
Serena and Gadam (Table 2). The addition of $\mathrm{N}$ had no significant effects on both panicle width and length while interactions between cropping system and $\mathrm{N}$ rate were inconsistent (Table 2; Figure 1).

3.3. Leaf Senescence at the Whole-Plant Level. Treatments showed significant differences in the number of leaves presenting more than $50 \%$ green leaf area during the entire sampling period and between the two sorghum varieties (Table 4). Leaf senescence significantly affected cropping system across sampling period 10 DAF (Igoji: $P<0.001$, Katumani: $P=0.043$ ), 20 DAF (Igoji: $P=0.020$, Katumani: $P=0.019$ ), 30 DAF (Igoji: $P=0.007$, Katumani: $P=0.050$ ), 40 DAF (Igoji: $P=0.010$, Katumani: $P=0.050$ ), and 50 DAF (Igoji: $P=0.009$, Katumani: $P=0.031$ ) (Table 4 ). Furthermore, the addition of $\mathrm{N}$ significantly delayed leaf senescence in both sites and across the sampling period $(P<0.001)$ (Table 4$)$. However, the effect of cropping system $\times N$ rate interaction on leaf senescence at the wholeplant level was inconsistent across the sampling period (Days after Flowering (DAF)) in both experimental sites (Table 4). In both sites, intercropping Gadam and Serena with either cowpea variety delayed leaf senescence by 0.1 and 0.2 leaves plant ${ }^{-1} \cdot$ day $^{-1}$, respectively (Table 4$)$. Nonetheless, interactions between cowpea variety and sorghum variety on leaf senescence at the whole-plant level were not detected.

The addition of $\mathrm{N}$ significantly prolonged leaf greenness by 0.4 leaves plant $^{-1}$ day $^{-1}$ compared with control plots but with little effects detected between 40 and $80 \mathrm{~kg} \mathrm{Nha}^{-1}$ in all sampling stages (Table 5). In both experimental sites, cropping system $\times N$ rate significantly affected leaf senescence at the whole-plant level at 10 DAF (Igoji: $P=0.046$, Katumani: $P=0.034$ ), 20 DAF (Igoji: $P=0.021$, Katumani: $P=0.042$ ), 40 DAF (Igoji: $P=0.046$, Katumani: $P=0.024$ ), and 50 DAF (Igoji: $P=0.001$, Katumani: $P=0.031$ ) (Table 4, Figure 2). Further, while leaf senescence at the whole-plant level increased with crop maturity, the addition of $\mathrm{N}$ delayed senescence where a higher number of leaves with over $50 \%$ green leaf area were recorded in plots fertilized with $\mathrm{N}$ compared with control plots under sole and intercrop system but no difference was detected between 40 and $80 \mathrm{~kg} \mathrm{Nha}^{-1}$ (Figure 2).

\subsection{Senescence of the Flag Leaf}

3.4.1. Peak Leaf Greenness (SPADmax). Cropping systems in Igoji $(P=0.047)$ and Katumani $(P=0.0148), \mathrm{N}$ rates in Igoji $(P<0.001)$ and Katumani $(P=0.004)$, and cropping system $\times N$ rate only in Igoji $(P=0.003)$ significantly affected the peak greenness of the flag leaf (SPADmax) (Table 5). Gadam was seven SPAD units greener than Serena in Igoji (wetter environment), but no significant differences were observed in Katumani which is drier than the former (Table 5). Irrespective of cowpea variety, intercropping significantly reduced SPADmax by 8 SPAD units, compared with the sole crop system in Igoji, but in Katumani, intercropping effects were marginal (Table 5). In Igoji, the addition of $80 \mathrm{~kg} \cdot \mathrm{N} \cdot \mathrm{ha}^{-1}$ significantly increased SPADmax by 
TABLE 1: Monthly rainfall and temperature from flowering to physiological maturity of sorghum during 2018/2019 short rains at the KALRO research stations in Igoji and Katumani.

\begin{tabular}{|c|c|c|c|c|c|c|c|c|}
\hline \multirow{2}{*}{ Months } & \multicolumn{4}{|c|}{ Igoji } & \multicolumn{4}{|c|}{ Katumani } \\
\hline & Jan-19 & Feb-19 & Mar-19 & Apr-19 & Jan-19 & Feb-19 & Mar-19 & Apr-19 \\
\hline Average temperature $\left({ }^{\circ} \mathrm{C}\right)$ & 35.0 & 39.0 & 155.0 & 398.0 & 16.8 & 3.8 & 8.4 & 3.0 \\
\hline Monthly rainfall (mm) & 19.9 & 20.5 & 21.1 & 20.5 & 19.4 & 21.1 & 21.6 & 22.0 \\
\hline
\end{tabular}

TABLE 2: Sorghum grain yield, panicle weight, 1000-seed weight, panicle width, and length of two sorghum varieties (Gadam and Serena) grown in sole and intercrop system with two varieties of cowpea (K80 and M66) and at three N rates at the KALRO research stations in Igoji and Katumani during 2018/2019 short rains season.

\begin{tabular}{|c|c|c|c|c|c|c|c|c|c|c|}
\hline \multirow[b]{2}{*}{ Treatments } & \multicolumn{5}{|c|}{ Igoji } & \multicolumn{5}{|c|}{ Katumani } \\
\hline & $\begin{array}{c}\text { Grain } \\
\text { yield } \\
\left(\mathrm{t} \cdot \mathrm{ha}^{-1}\right)\end{array}$ & $\begin{array}{c}\text { Panicle } \\
\text { weight } \\
\text { (g) }\end{array}$ & $\begin{array}{l}1000 \text {-seed } \\
\text { weight }(\mathrm{g})\end{array}$ & $\begin{array}{c}\text { Panicle } \\
\text { width } \\
(\mathrm{cm})\end{array}$ & $\begin{array}{c}\text { Panicle } \\
\text { length } \\
(\mathrm{cm})\end{array}$ & $\begin{array}{c}\text { Grain } \\
\text { yield (t } \\
\left.\text { ha }^{-1}\right)\end{array}$ & $\begin{array}{c}\text { Panicle } \\
\text { weight }(\mathrm{g})\end{array}$ & $\begin{array}{l}1000 \text {-seed } \\
\text { weight }(\mathrm{g})\end{array}$ & $\begin{array}{c}\text { Panicle } \\
\text { width } \\
(\mathrm{cm})\end{array}$ & $\begin{array}{c}\text { Panicle } \\
\text { length }(\mathrm{cm})\end{array}$ \\
\hline \multicolumn{11}{|c|}{ Cropping system (CS) } \\
\hline Sole Gadam & $3.15 \mathrm{a}$ & $35.9 \mathrm{a}$ & $31.1 \mathrm{a}$ & $13.6 \mathrm{~b}$ & $19.6 \mathrm{ab}$ & $3.09 a$ & $31.5 \mathrm{ab}$ & $33.6 \mathrm{a}$ & $6.3 \mathrm{ab}$ & $7.9 \mathrm{a}$ \\
\hline Gadam + K80 & $1.48 \mathrm{bc}$ & $29.2 \mathrm{ab}$ & $30.7 \mathrm{a}$ & $6.8 c$ & $17.8 \mathrm{ab}$ & $0.89 c$ & $24.2 \mathrm{c}$ & $29.1 \mathrm{~b}$ & $6.8 \mathrm{a}$ & $8.0 \mathrm{a}$ \\
\hline Gadam + M66 & $1.27 \mathrm{bc}$ & $27.6 \mathrm{~b}$ & $30.9 a$ & $5.1 \mathrm{~d}$ & $15.0 \mathrm{~b}$ & $1.43 \mathrm{~b}$ & $27.6 b c$ & $32.9 \mathrm{a}$ & $5.1 \mathrm{~b}$ & $6.4 \mathrm{~b}$ \\
\hline Sole Serena & $1.82 \mathrm{~b}$ & $36.1 \mathrm{a}$ & $27.4 \mathrm{~b}$ & $15.3 \mathrm{a}$ & $21.3 \mathrm{a}$ & $2.76 a$ & $34.6 a$ & $30.1 \mathrm{~b}$ & $6.7 \mathrm{a}$ & $8.5 \mathrm{a}$ \\
\hline Serena + K80 & $1.06 \mathrm{bc}$ & $29.2 b$ & $26.1 b$ & $5.9 \mathrm{~cd}$ & $7.5 \mathrm{c}$ & $1.10 b c$ & $27.6 \mathrm{bc}$ & $26.3 \mathrm{c}$ & $6.5 \mathrm{ab}$ & $7.5 \mathrm{ab}$ \\
\hline Serena + M66 & $0.95 c$ & $27.6 \mathrm{~b}$ & $31.0 \mathrm{a}$ & $6.5 c$ & $16.8 \mathrm{ab}$ & $1.27 b c$ & $26.1 \mathrm{bc}$ & $30.7 b$ & $5.9 \mathrm{ab}$ & $8.6 \mathrm{a}$ \\
\hline$P$-value & $<0.001$ & 0.039 & 0.002 & $<0.001$ & 0.002 & $<0.001$ & 0.044 & $<0.001$ & 0.013 & 0.017 \\
\hline \multicolumn{11}{|l|}{ N rate } \\
\hline $0 \mathrm{~kg} \cdot \mathrm{N} \cdot \mathrm{ha}^{-1}$ & $1.46 \mathrm{~b}$ & $31.4 \mathrm{a}$ & $30.06 \mathrm{a}$ & $8.7 \mathrm{a}$ & $15.4 \mathrm{~b}$ & $1.43 \mathrm{~b}$ & $26.7 \mathrm{a}$ & $30.33 a$ & $6.1 \mathrm{a}$ & $7.7 \mathrm{a}$ \\
\hline $40 \mathrm{~kg} \cdot \mathrm{N} \cdot \mathrm{ha}^{-1}$ & $1.57 \mathrm{~b}$ & $31.3 \mathrm{a}$ & $29.50 \mathrm{a}$ & $8.7 \mathrm{a}$ & $16.5 \mathrm{ab}$ & $1.96 \mathrm{a}$ & $28.7 \mathrm{a}$ & $30.72 \mathrm{a}$ & $6.0 \mathrm{a}$ & $7.9 \mathrm{a}$ \\
\hline $80 \mathrm{~kg} \cdot \mathrm{N} \cdot \mathrm{ha}^{-1}$ & $1.84 \mathrm{a}$ & $30.2 \mathrm{a}$ & $29.06 \mathrm{a}$ & $9.3 \mathrm{a}$ & $17.1 \mathrm{a}$ & $1.88 \mathrm{a}$ & $30.5 \mathrm{a}$ & $30.28 \mathrm{a}$ & $6.7 \mathrm{a}$ & $7.9 \mathrm{a}$ \\
\hline$P$-value & 0.015 & 0.352 & 0.341 & 0.207 & 0.076 & 0.013 & 0.256 & 0.803 & 0.089 & 0.725 \\
\hline $\begin{array}{l}P \text {-value } \\
\mathrm{CS} \times N\end{array}$ & $<.001$ & 0.352 & 0.236 & 0.034 & 0.01 & 0.031 & 0.282 & 0.761 & 0.66 & 0.13 \\
\hline
\end{tabular}

The means within a column followed by the same alphabets are statistically similar; CS $\times N$ : interaction between cropping system and $N$ rate; ns is not significant.

five units compared with control plots (Table 5). Similarly, in Katumani, the addition of $40 \mathrm{~kg} \mathrm{Nha}^{-1}$ significantly increased SPADmax by nine units compared with control but without significant differences between 40 and $80 \mathrm{~kg} \cdot \mathrm{N} \cdot \mathrm{ha}^{-}$ (Table 5). Cropping system $\times N$ rate effects on SPADmax were significantly large whereby the highest SPADmax was recorded under sole crop system with the addition of $\mathrm{N}$ while intercropping without $\mathrm{N}$ supply had the lowest SPADmax (Figure 3). Correlation analysis revealed that SPADmax was positively and significantly correlated with sorghum grain yield under both sole cropping system (Igoji: $R^{2}=0.82$, Katumani: $R^{2}=0.77$ ) and intercrop system (Igoji: $R^{2}=0.58$, Katumani: $R^{2}=0.76$ ) and 1000 -seed weight only under sole cropping system in both sites (Igoji: $R^{2}=0.71$, Katumani: $R^{2}=0.98$ ) (Table 3). However, SPADmax (peak leaf greenness) was weakly and insignificantly correlated with panicle width, panicle length, and panicle weight under both sole and intercrop systems in both experimental sites (Table 3).

3.4.2. Minimum SPAD (SPADmin). The minimum SPAD unit of the flag leaf (SPADmin) did not vary between Gadam and Serena and was not affected by the cropping system, $\mathrm{N}$ rate, and their interaction (Table 5). While SPADmin was not significantly affected by the main effects and their interactions, correlation analysis revealed that SPADmin was significantly correlated with sorghum grain yield under the sole cropping system (Igoji: $R^{2}=0.92$, Katumani: $R^{2}=0.82$ ) and intercrop system (Igoji: $R^{2}=0.75$, Katumani: $R^{2}=0.89$ ) (Table 3 ). However, SPADmin was weakly and inconsistently correlated with other yield treats (seed weight, panicle width, panicle length, and panicle weight) (Table 3).

3.4.3. Time to Loss of 50\% Maximum SPADmax (EC50). No significant difference was observed between the two sorghum varieties on time to loss of $50 \%$ maximum SPADmax (EC50) (Table 5). Further, EC50 was not significantly affected by the cropping system in both experimental sites; however, the $N$ rate effect was significant on EC50 in Igoji $(P=0.023)$ and Katumani $(P<0.001)(\mathrm{Ta}-$ ble 5). In Igoji, EC50 was delayed by 7.5 days with the addition of $80 \mathrm{~kg} \cdot \mathrm{N} \cdot \mathrm{ha}^{-1}$ while in Katumani, leaf senescence was delayed by 11 days compared with unfertilized plots but no difference was detected between the addition of 80 and $40 \mathrm{~kg} \cdot \mathrm{N} \cdot \mathrm{ha}^{-1}$ (Table 5). On the other hand, the cropping system $\times N$ rate had no significant effect on EC50 in both experimental sites (Table 5). Correlation analysis revealed that EC50 was weakly and insignificantly correlated with grain yield and yield traits under both sole and intercrop systems in Igoji and Katumani experimental sites (Table 3). 


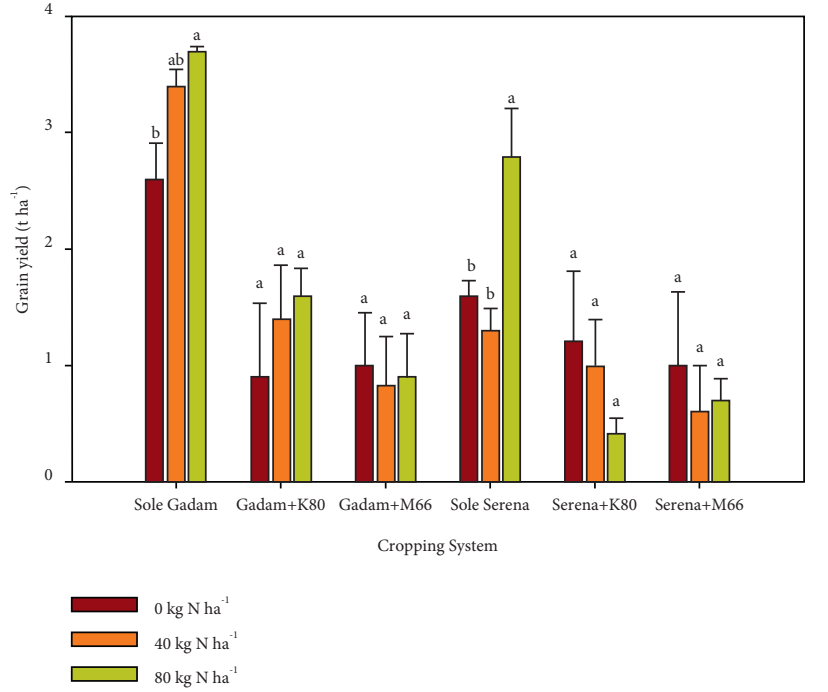

(a)

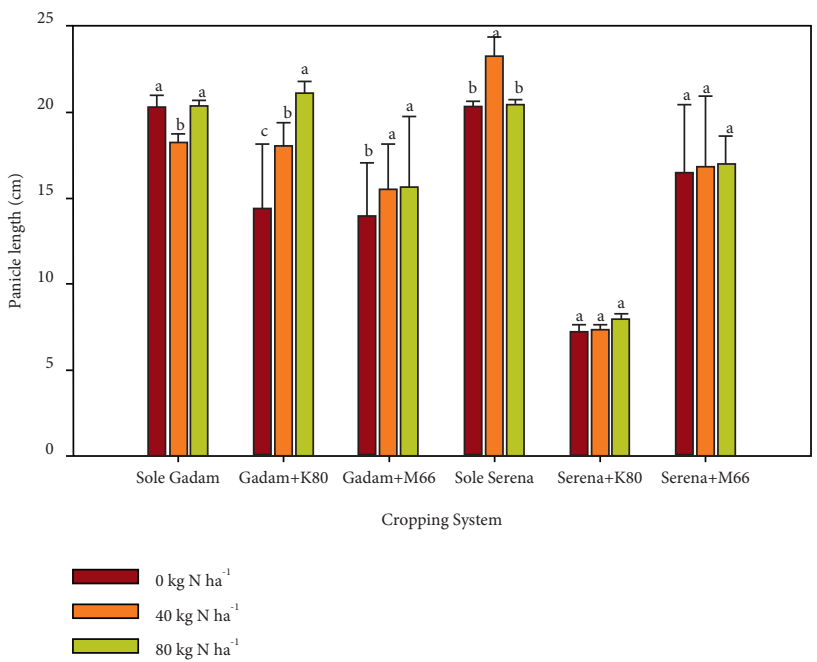

(c)

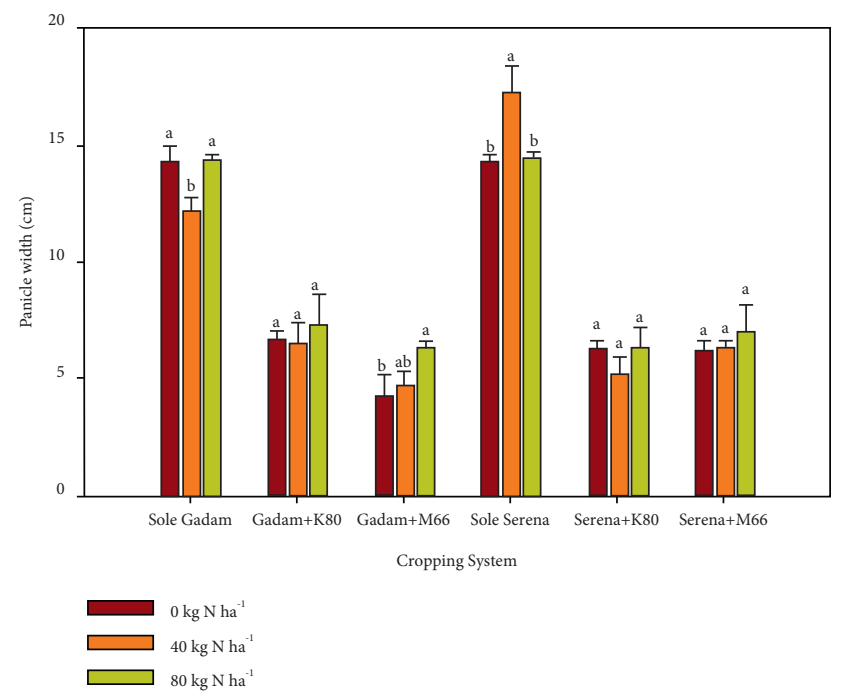

(e)

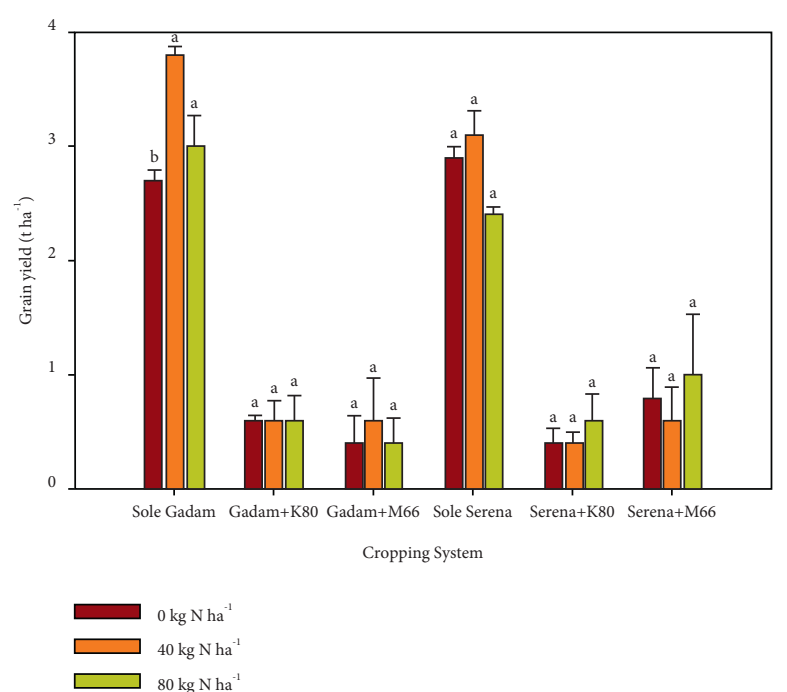

(b)

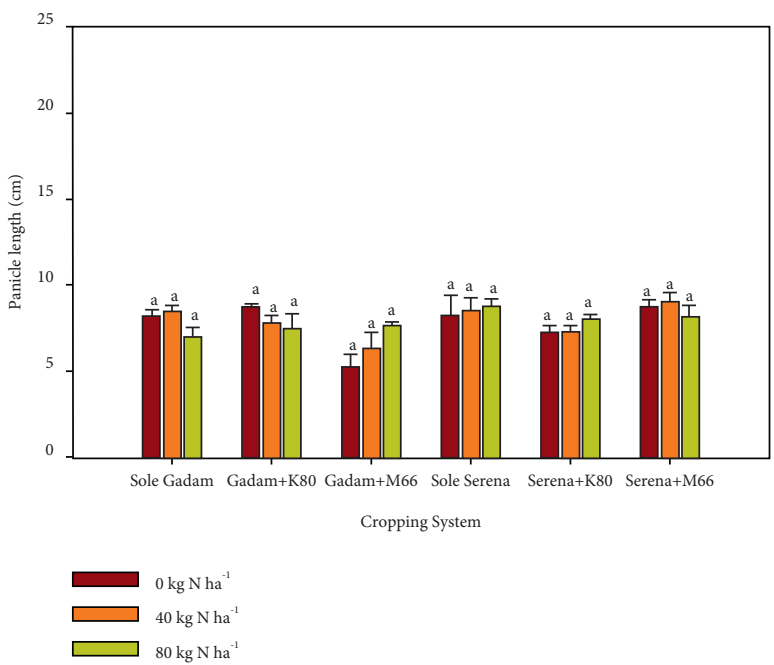

(d)

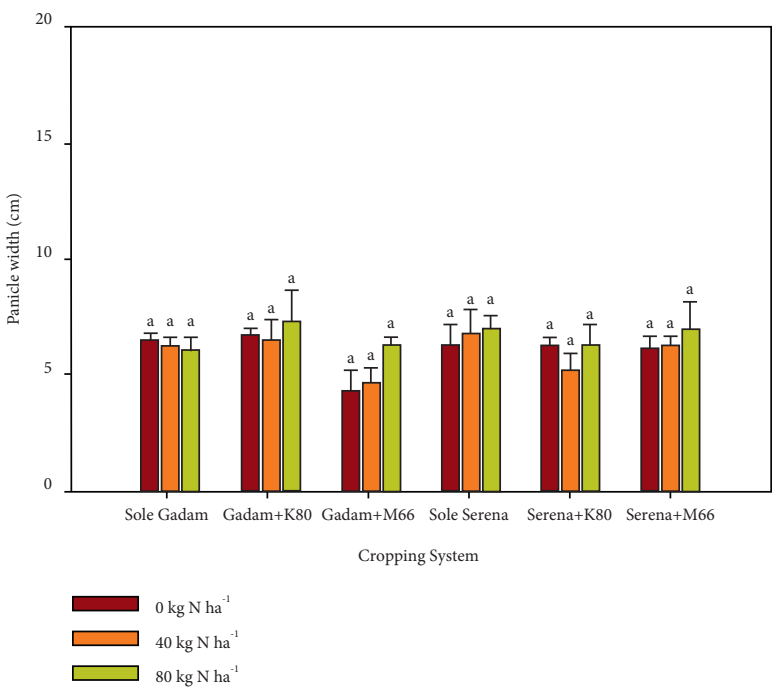

(f)

FIGURE 1: Sorghum grain yield, panicle width, and panicle length of two sorghum varieties (Gadam and Serena) grown in sole and intercrop system with two varieties of cowpea (K80 and M66) in interaction with 0, 40, and $80 \mathrm{~kg} \cdot \mathrm{N} \cdot \mathrm{ha}^{-1}$ at the KALRO, Igoji (a, c, e) and Katumani (b, d, f) research station during 2018/2019 short rains season. Mean values followed by the same letter are not significantly different. The bars indicate the mean standard errors (SE). 
TABLE 3: Correlation coefficients between senescence traits and sorghum grain yield and yield parameters of two sorghum varieties (Gadam and Serena) grown in an intercrop system with two varieties of cowpea (K80 and M66) at 0, 40, and $80 \mathrm{~kg} \cdot \mathrm{N} \cdot \mathrm{ha}^{-1} \mathrm{during} 2018 / 2019$ short rains at the KALRO research stations in Igoji and Katumani during the 2018/2019 short rain season.

\begin{tabular}{lccccccccc}
\hline \multirow{2}{*}{ Cropping system } & \multirow{2}{*}{ Traits } & \multicolumn{4}{c}{ Igoji } & \multicolumn{3}{c}{ Katumani } \\
& & SPADmax & SPADmin & EC50 & RS & SPADmax & SPADmin & EC50 & RS \\
\hline & Grain yield & $0.82^{*}$ & $0.92^{*}$ & $-0.14 \mathrm{~ns}$ & $0.93^{*}$ & $0.77^{*}$ & $0.82^{*}$ & $0.05 \mathrm{~ns}$ & $0.75 \mathrm{~ns}$ \\
Sole & Panicle length & $-0.53 \mathrm{~ns}$ & $0.94^{*}$ & $-0.19 \mathrm{~ns}$ & $0.79 \mathrm{~ns}$ & $-0.39 \mathrm{~ns}$ & $0.09 \mathrm{~ns}$ & $0.38 \mathrm{~ns}$ & $0.33 \mathrm{~ns}$ \\
& Panicle width & $-0.53 \mathrm{~ns}$ & $0.55 \mathrm{~ns}$ & $0.32 \mathrm{~ns}$ & $0.32 \mathrm{~ns}$ & $0.89 \mathrm{~ns}$ & $0.96^{*}$ & $0.42 \mathrm{~ns}$ & $-0.24 \mathrm{~ns}$ \\
& Panicle weight & $0.18 \mathrm{~ns}$ & $0.9 \mathrm{~ns}$ & $0.16 \mathrm{~ns}$ & $0.72 \mathrm{~ns}$ & $0.44 \mathrm{~ns}$ & $0.25 \mathrm{~ns}$ & $0.43 \mathrm{~ns}$ & $-0.18 \mathrm{~ns}$ \\
& 1000 -seed weight & $0.71^{*}$ & $0.5 \mathrm{~ns}$ & $0.18 \mathrm{~ns}$ & $0.81 \mathrm{~ns}$ & $0.95^{*}$ & $0.76^{*}$ & $0.51 \mathrm{~ns}$ & $-0.07 \mathrm{~ns}$ \\
\hline \multirow{3}{*}{ Intercrop } & Grain yield & $0.58^{*}$ & $0.75^{*}$ & $0.13 \mathrm{~ns}$ & $0.03 \mathrm{~ns}$ & $0.76^{*}$ & $0.89^{* *}$ & $0.15 \mathrm{~ns}$ & $-0.07 \mathrm{~ns}$ \\
& Panicle length & $0.10 \mathrm{~ns}$ & $0.001 \mathrm{~ns}$ & $-0.05 \mathrm{~ns}$ & $0.34 \mathrm{~ns}$ & $0.44 \mathrm{~ns}$ & $0.46 \mathrm{~ns}$ & $0.09 \mathrm{~ns}$ & $0.38 \mathrm{~ns}$ \\
& Panicle width & $0.45 \mathrm{~ns}$ & $0.37 \mathrm{~ns}$ & $0.51 \mathrm{~ns}$ & $0.26 \mathrm{~ns}$ & $0.52 \mathrm{~ns}$ & $0.37 \mathrm{~ns}$ & $0.22 \mathrm{~ns}$ & $0.10 \mathrm{~ns}$ \\
& Panicle weight & $-0.57 \mathrm{~ns}$ & $-0.55 \mathrm{~ns}$ & $-0.37 \mathrm{~ns}$ & $-0.04 \mathrm{~ns}$ & $0.10 \mathrm{~ns}$ & $0.13 \mathrm{~ns}$ & $0.14 \mathrm{~ns}$ & $-0.003 \mathrm{~ns}$ \\
& 1000-seed weight & $-0.31 \mathrm{~ns}$ & $-0.28 \mathrm{~ns}$ & $-0.50 \mathrm{~ns}$ & $0.11 \mathrm{~ns}$ & $0.14 \mathrm{~ns}$ & $0.005 \mathrm{~ns}$ & $0.20 \mathrm{~ns}$ & $0.27 \mathrm{~ns}$ \\
\hline
\end{tabular}

SPADmin: minimum leaf greenness; SPADmax: maximum leaf greenness; EC50: time to loss of 50\% SPADmax; RS: rate of senescence; ns: not significant; ${ }^{*} P<0.05 ;{ }^{* *} P<0.01 ; n=54$.

TABLE 4: Number of green leaves at 10, 20, 30, 40, and 50 days after flowering (DAF) of two sorghum varieties (Gadam and Serena) grown in sole and intercrop system with two varieties of cowpea (K80 and M66) and three N rates at the KALRO, Igoji, and Katumani research station during 2018/2019 short rains season.

\begin{tabular}{|c|c|c|c|c|c|c|c|c|c|c|}
\hline \multirow{2}{*}{ Treatment } & \multicolumn{5}{|c|}{ Igoji } & \multicolumn{5}{|c|}{ Katumani } \\
\hline & 10 & 20 & 30 & 40 & 50 & 10 & 20 & 30 & 40 & 50 \\
\hline \multicolumn{11}{|c|}{ Cropping system (CS) } \\
\hline Sole Gadam & $5.8 \mathrm{c}$ & $6.1 b$ & $6.0 \mathrm{~b}$ & $3.6 \mathrm{~b}$ & $2.3 c$ & $4.4 \mathrm{bc}$ & $4.3 \mathrm{~b}$ & $3.4 \mathrm{ab}$ & $3.0 \mathrm{bc}$ & $2.1 \mathrm{~b}$ \\
\hline Gadam + K80 & $6.6 \mathrm{ab}$ & $6.7 \mathrm{ab}$ & $7.4 \mathrm{a}$ & $4.4 \mathrm{a}$ & $3.4 \mathrm{a}$ & $4.9 \mathrm{a}$ & $4.4 \mathrm{~b}$ & $3.2 \mathrm{~b}$ & $2.7 \mathrm{~cd}$ & $2.0 \mathrm{~b}$ \\
\hline Gadam + M66 & $6.4 \mathrm{ab}$ & $6.7 \mathrm{ab}$ & $7.7 \mathrm{a}$ & $4.7 \mathrm{a}$ & $3.7 \mathrm{a}$ & $5.0 \mathrm{a}$ & $4.9 \mathrm{a}$ & $3.8 \mathrm{a}$ & $3.6 \mathrm{a}$ & $2.8 \mathrm{a}$ \\
\hline Sole Serena & $6.0 \mathrm{bc}$ & $6.7 \mathrm{ab}$ & $6.0 \mathrm{~b}$ & $4.3 \mathrm{a}$ & $2.7 \mathrm{bc}$ & $4.3 \mathrm{c}$ & $3.7 \mathrm{c}$ & $2.9 c$ & $2.3 \mathrm{~d}$ & $1.4 \mathrm{c}$ \\
\hline Serena + K80 & $6.1 b c$ & $6.7 \mathrm{ab}$ & $7.8 \mathrm{a}$ & $4.6 \mathrm{a}$ & $2.9 \mathrm{~b}$ & $4.9 \mathrm{a}$ & $4.8 \mathrm{a}$ & $3.8 \mathrm{a}$ & $3.2 \mathrm{ab}$ & $2.3 \mathrm{~b}$ \\
\hline Serena + M66 & $6.8 \mathrm{a}$ & $7.2 \mathrm{a}$ & $6.8 \mathrm{ab}$ & $4.8 \mathrm{a}$ & $3.6 \mathrm{a}$ & $4.8 \mathrm{ab}$ & $4.4 \mathrm{~b}$ & $3.7 \mathrm{a}$ & $2.7 \mathrm{~cd}$ & $2.0 \mathrm{~b}$ \\
\hline$P$ value & $<0.001$ & 0.020 & 0.007 & 0.010 & 0.009 & 0.043 & 0.019 & 0.050 & 0.05 & 0.031 \\
\hline \multicolumn{11}{|l|}{ N rate } \\
\hline $0 \mathrm{~kg} \cdot \mathrm{N} \cdot \mathrm{ha}^{-1}$ & $3.8 \mathrm{~b}$ & $4.3 b$ & $5.5 b$ & $2.0 \mathrm{~b}$ & $0.9 \mathrm{~b}$ & $2.9 \mathrm{~b}$ & $2.6 \mathrm{~b}$ & $1.5 b$ & $1.0 \mathrm{~b}$ & $0.2 \mathrm{~b}$ \\
\hline $40 \mathrm{~kg} \cdot \mathrm{N} \cdot \mathrm{ha}^{-1}$ & $7.6 \mathrm{a}$ & $8.0 \mathrm{a}$ & $7.7 \mathrm{a}$ & $5.6 \mathrm{a}$ & $4.1 \mathrm{a}$ & $5.7 \mathrm{a}$ & $5.3 \mathrm{a}$ & $4.4 \mathrm{a}$ & $3.9 \mathrm{a}$ & $3.1 \mathrm{a}$ \\
\hline $80 \mathrm{~kg} \cdot \mathrm{N} \cdot \mathrm{ha}^{-1}$ & $7.4 \mathrm{a}$ & $7.7 \mathrm{a}$ & $7.6 \mathrm{a}$ & $5.6 \mathrm{a}$ & $4.3 \mathrm{a}$ & $5.6 \mathrm{a}$ & $5.4 \mathrm{a}$ & $4.4 \mathrm{a}$ & $3.8 \mathrm{a}$ & $3.1 \mathrm{a}$ \\
\hline$P$ value & $<0.001$ & $<0.001$ & $<0.001$ & $<0.001$ & $<0.001$ & $<0.001$ & $<0.001$ & $<0.001$ & $<0.001$ & $<0.001$ \\
\hline$P$ value $\mathrm{CS} \times N$ & 0.046 & 0.021 & 0.329 & 0.046 & 0.001 & 0.034 & 0.042 & 0.363 & 0.024 & 0.031 \\
\hline
\end{tabular}

The means within a column followed by the same alphabets are statistically similar, CS $\times N$ : interaction between cropping system and $N$ rate; ns is not significant.

3.4.4. Rate of Senescence. Significant effects of the cropping system on the rate of senescence were observed in Katumani $(P=0.006)$ but not in Igoji $(P>0.05)$ (Table 5). Under the sole crop system, Gadam senesced faster than Serena, but only in Katumani (Table 5). Cropping system $\times N$ rate interaction had no significant effect on the rate of senescence in both sites (Table 5). Intercropping Gadam with either K80 or M66 significantly reduced the rate of senescence by four SPAD units day ${ }^{-1}$ but there were no differences in Serena. Application of $80 \mathrm{~kg} \cdot \mathrm{N} \cdot \mathrm{ha}^{-1}$ increased the rate of senescence by $2.6 \mathrm{SPAD}$ units day ${ }^{-1}$ compared with control plots but no significant differences between 40 and $80 \mathrm{~kg} \cdot \mathrm{N} \cdot \mathrm{ha}^{-1}$ were observed (Table 5). Correlation analysis between the rate of senescence and sorghum grain yield revealed a positive and significant correlation under sole crop system only in the wetter environment (Igoji) $\left(R^{2}=0.93\right)$; however, it insignificantly correlated with grain yield under intercrop system in both sites (Table 3). Additionally, the rate of senescence was inconsistently and weakly correlated with sorghum yield traits under sole and intercrop systems in both experimental sites (Table 3).

\section{Discussion}

While senescence is regulated by genetics and environmental cues, manipulation of cropping systems can significantly modulate this trait and the final grain yield and quality. The present results provide insights into the effect of intercropping and $\mathrm{N}$ rate on postflowering senescence of sorghum leaf. Further, associations between sorghum grain yield and the traits of leaf senescence are revealed in the reinforcement of previous work. Intercropping significantly reduced grain yield by about $50 \%$ compared with sole crops. Further, intercropping delayed leaf senescence at the whole plant by 0.2 leaves plant ${ }^{-1} \mathrm{day}^{-1}$ but reduced SPADmax of the flag by 8 SPAD units compared with the 
TABLE 5: Maximum leaf greenness (SPADmax), minimum leaf greenness (SPADmin), time to loss of 50\% SPADmax (EC50), and the rate of leaf senescence (RS) means of two sorghum varieties (Gadam and Serena) grown in sole and intercrop system with two varieties of cowpea (K80 and M66) and N rate at the KALRO research stations in Igoji and Katumani during 2018/2019 short rains season.

\begin{tabular}{|c|c|c|c|c|c|c|c|c|}
\hline \multirow[b]{2}{*}{ Treatments } & \multicolumn{4}{|c|}{ Igoji } & \multicolumn{4}{|c|}{ Katumani } \\
\hline & $\begin{array}{l}\text { SPADmax } \\
\text { (SPAD units) }\end{array}$ & $\begin{array}{l}\text { SPADmin } \\
\text { (SPAD units) }\end{array}$ & $\begin{array}{l}\text { EC50 } \\
\text { (days) }\end{array}$ & $\begin{array}{l}\text { RS (SPAD } \\
\text { units day }{ }^{-1} \text { ) }\end{array}$ & $\begin{array}{l}\text { SPADmax } \\
\text { (SPAD units) }\end{array}$ & $\begin{array}{l}\text { SPADmin } \\
\text { (SPAD units) }\end{array}$ & $\begin{array}{l}\text { EC50 } \\
\text { (days) }\end{array}$ & $\begin{array}{c}\text { RS } \\
\left(\text { SPAD units day }^{-1}\right)\end{array}$ \\
\hline \multicolumn{9}{|c|}{ Cropping systems (CS) } \\
\hline Sole Gadam & $49.73 a$ & $10.08 \mathrm{a}$ & $31.43 \mathrm{a}$ & $6.39 a$ & $61.48 \mathrm{ab}$ & $15.41 \mathrm{a}$ & $23.95 \mathrm{a}$ & $8.53 a$ \\
\hline Gadam + K80 & $40.77 b$ & $14.38 \mathrm{a}$ & $29.49 \mathrm{a}$ & $5.16 \mathrm{a}$ & $64.18 \mathrm{a}$ & $17.17 \mathrm{a}$ & $22.72 \mathrm{a}$ & $4.41 \mathrm{~b}$ \\
\hline Gadam + M66 & $42.30 \mathrm{~b}$ & $14.79 \mathrm{a}$ & $27.08 \mathrm{a}$ & $4.17 \mathrm{a}$ & $55.90 \mathrm{ab}$ & $15.40 \mathrm{a}$ & $25.15 a$ & $4.55 \mathrm{~b}$ \\
\hline Sole Serena & $42.70 \mathrm{~b}$ & $13.33 \mathrm{a}$ & $31.38 \mathrm{a}$ & $5.25 \mathrm{a}$ & $57.04 \mathrm{ab}$ & $16.32 \mathrm{a}$ & $24.27 \mathrm{a}$ & $4.96 \mathrm{~b}$ \\
\hline Serena + K80 & $42.36 \mathrm{~b}$ & $15.08 \mathrm{a}$ & $30.14 a$ & $3.71 \mathrm{a}$ & $51.60 \mathrm{~b}$ & $16.11 \mathrm{a}$ & $22.82 \mathrm{a}$ & $4.84 \mathrm{~b}$ \\
\hline Serena + M66 & $41.03 b$ & $12.73 \mathrm{a}$ & $22.55 \mathrm{a}$ & $4.04 \mathrm{a}$ & $51.49 \mathrm{~b}$ & $16.93 \mathrm{a}$ & $28.12 \mathrm{a}$ & $5.03 \mathrm{~b}$ \\
\hline$P$ value & 0.047 & 0.311 & 0.669 & 0.683 & 0.0148 & 0.992 & 0.347 & 0.006 \\
\hline \multicolumn{9}{|l|}{$N$ rates } \\
\hline $0 \mathrm{~kg} \cdot \mathrm{N} \cdot \mathrm{ha}^{-1}$ & $41.52 \mathrm{~b}$ & $12.95 \mathrm{a}$ & $26.21 b$ & $3.10 \mathrm{~b}$ & $49.17 b$ & $14.26 \mathrm{a}$ & $17.62 \mathrm{~b}$ & $4.83 a$ \\
\hline $40 \mathrm{~kg} \cdot \mathrm{N} \cdot \mathrm{ha}^{-1}$ & $41.25 b$ & $12.23 \mathrm{a}$ & $26.03 b$ & $5.51 \mathrm{a}$ & $62.35 \mathrm{a}$ & $16.16 \mathrm{a}$ & $26.64 a$ & $5.19 \mathrm{a}$ \\
\hline $80 \mathrm{~kg} \cdot \mathrm{N} \cdot \mathrm{ha}^{-1}$ & $46.67 \mathrm{a}$ & $15.01 \mathrm{a}$ & $33.80 \mathrm{a}$ & $5.74 \mathrm{a}$ & $59.33 \mathrm{a}$ & $18.25 \mathrm{a}$ & $29.25 a$ & $6.14 \mathrm{a}$ \\
\hline$P$ value & $<.001$ & 0.408 & 0.023 & 0.044 & 0.004 & 0.132 & $<.001$ & 0.49 \\
\hline$P$ value $\mathrm{CS} \times N$ & 0.003 & 0.606 & 0.332 & 0.127 & 0.043 & 0.094 & 0.252 & 0.142 \\
\hline
\end{tabular}

The means within a column followed by the same alphabets are statistically similar, CS: cropping system, CS $\times N$ : interaction between cropping system and $\mathrm{N}$ rate, ns: not significant.

sole crop system. Fertilizer $\mathrm{N}$ application significantly increased leaf greenness and delayed senescence at the whole plant and flag leaf level. Cropping system $\times$ nitrogen interactions modulated senescence at the whole plant and flag leaf scales and sorghum grain yield. Sorghum grain yield was a function of SPADmax, SPADmin, and rate of leaf senescence but EC50 was insignificantly correlated with grain yield.

4.1. Grain Yield and Yield Traits. Grain yields of intercropped Gadam and Serena were significantly reduced by about $50 \%$ compared with yields of sole crops. This could be attributed to interspecies competition for resources like soil nutrients, sunlight, and water in the intercropped sorghum [13]. Previous study on sorghum-cowpea intercropping in semiarid environment reported intercropping significantly reduced sorghum grain yield by $37 \%$ [1]. Further, a study on sorghum-legume intercropping in dry environment reported that sole sorghum exceeded $31.0 \%$ of the intercropped sorghum yield which was attributed to competition for light, nutrients, and water in intercrop system [2]. While sorghum grain yield was decreased by about $50 \%$ in the present study, other previous studies have reported that sorghum grain yield was increased in a sorghum-legume intercropping system $[30,31]$. This could be attributed to differences in the test crops used in this study and study environment; hence, screening of cowpea varieties compatible for intercropping with sorghum is required. Since intercropping significantly reduced sorghum grain yield in both sites irrespective of the difference in agroecological conditions between Igoji and Katumani, this suggests that sole cropping system was effective in increasing the individual grain yields of sorghum since growth resources can be utilized without competition from companion crop compared with an intercrop system.
Further, sorghum grain yield in the present study was significantly increased by $27 \%$ with the addition of $\mathrm{N}$ compared with control plots in both sites but without any differences detected between the addition of 40 and $80 \mathrm{~kg} \cdot \mathrm{N} \cdot \mathrm{ha}^{-1}$. This could be attributed to the important role of $\mathrm{N}$ in increasing the growth and development of plant reproductive parts and photosynthetic capacity that resulted in higher yields. The results are in agreement with both the study hypothesis and previous studies. An earlier study reported that the maximum sorghum grain yield was produced in $\mathrm{N}$-fertilized plots while the lowest grain yield was produced in control plots without fertilizer $\mathrm{N}$ addition [18]. Further, the results of this study are consistent with the findings of Sibhatu and Belete [2] who found that the maximum grain yield of sorghum was attained with the addition of $41 \mathrm{~kg} \cdot \mathrm{N} \cdot \mathrm{ha}^{-1}$ while a similar study on barley reported $\mathrm{N}$ fertilization increased grain yield of barley [12]. Further, the lack of significant difference in grain yield and yield traits between the addition of 40 and $80 \mathrm{~kg} \cdot \mathrm{N} \cdot \mathrm{ha}^{-1}$ suggests that sorghum grain yield can be maximized at lower $N$ rates. In Igoji, cropping system $\times$ nitrogen interactions were significant where the highest mean grain yield was recorded under sole but the only marginal increase in intercrop system was observed. This could have been attributed to nonproportional sharing of soil $\mathrm{N}$ sources resulting from competition between sorghum and cowpea and limited fixation of $\mathrm{N}$ by the cowpea in an intercrop system resulting in low grain yield in an intercrop system as opposed to sole cropping system where intraspecies competition for growth resources (nutrients, water, light, and space) might have been minimal [32]. However, although intercropping reduced sorghum yield, the present results show that there is potential to exploit cropping system $\times N$ interactions to increase yields, more so in wet environments (Igoji) than in areas with low rainfall (Katumani). Further, future studies should consider evaluating sorghum yield performance 


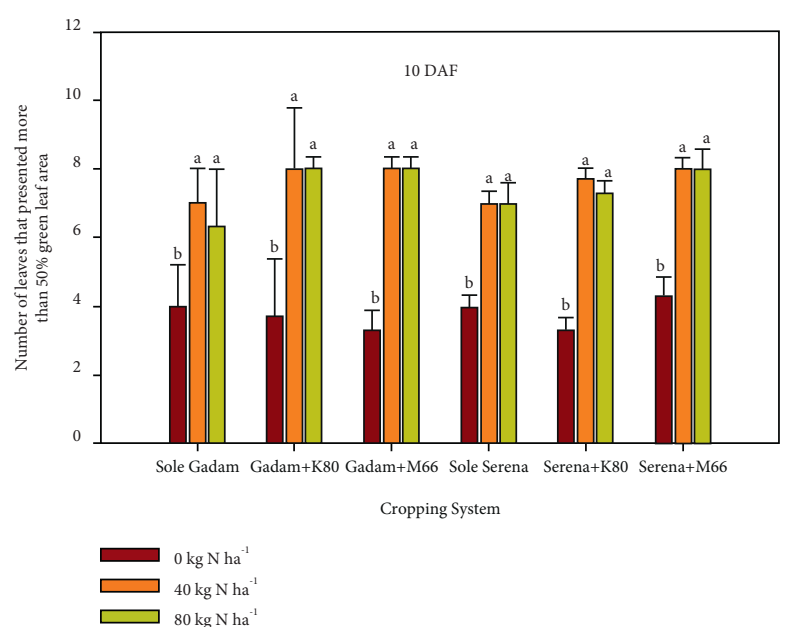

(a)

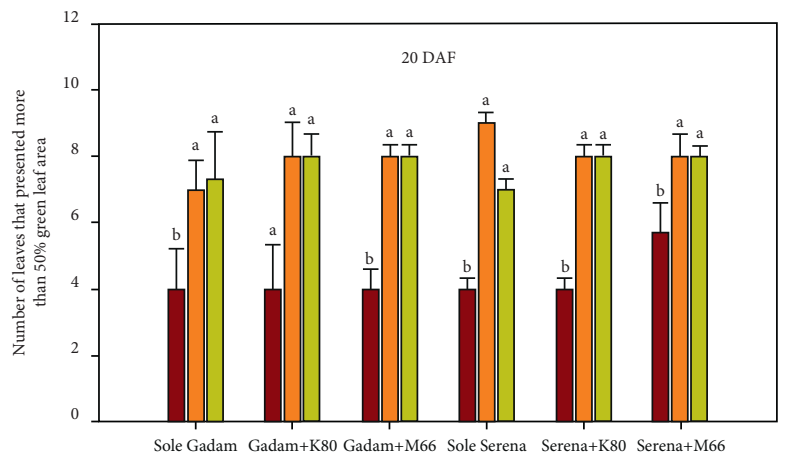

Cropping System

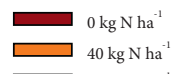

$\square 0 \mathrm{~kg} \mathrm{~N} \mathrm{ha}^{-1}$
$\square 0 \mathrm{~kg} \mathrm{Nha}^{-1}$

(c)

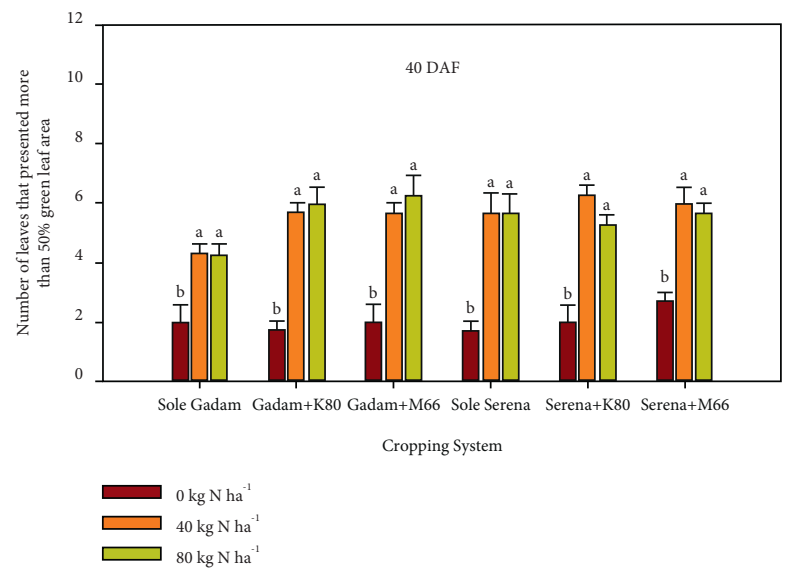

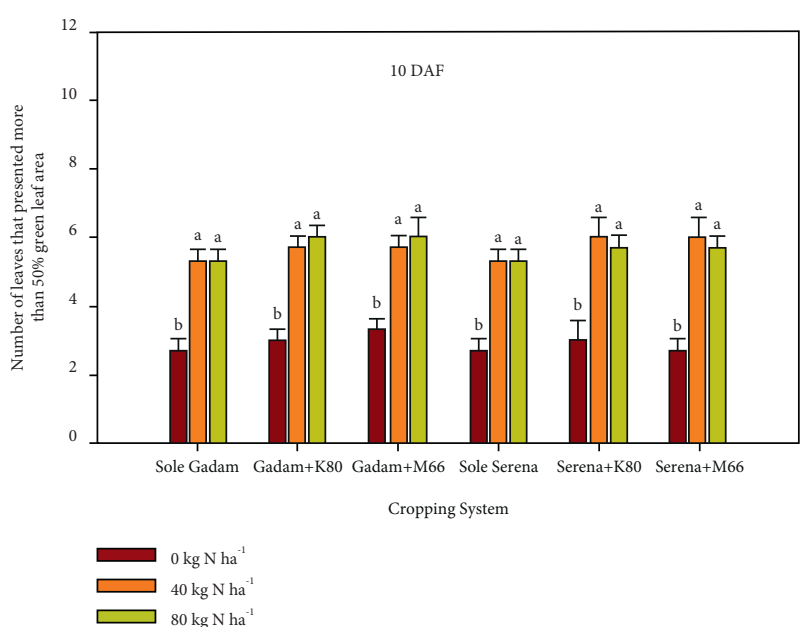

(b)

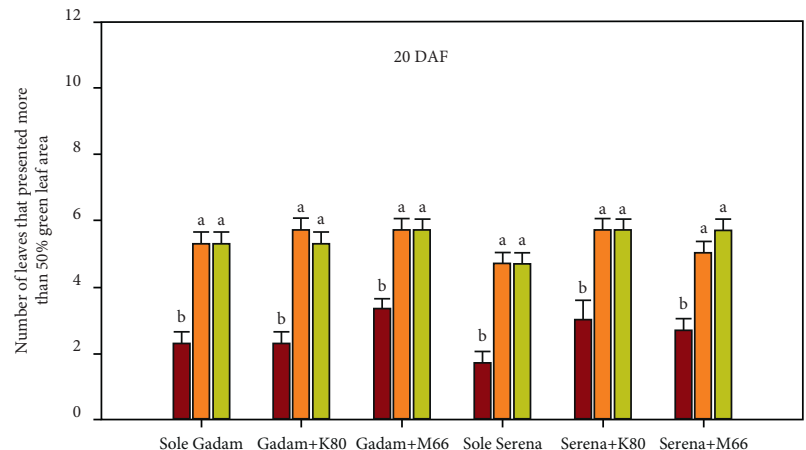

Cropping System

$0 \mathrm{~kg} \mathrm{Nha}^{-1}$
$40 \mathrm{~kg} \mathrm{Nha}^{-1}$

$\square 80 \mathrm{~kg} \mathrm{Nha}^{-1}$

(d)

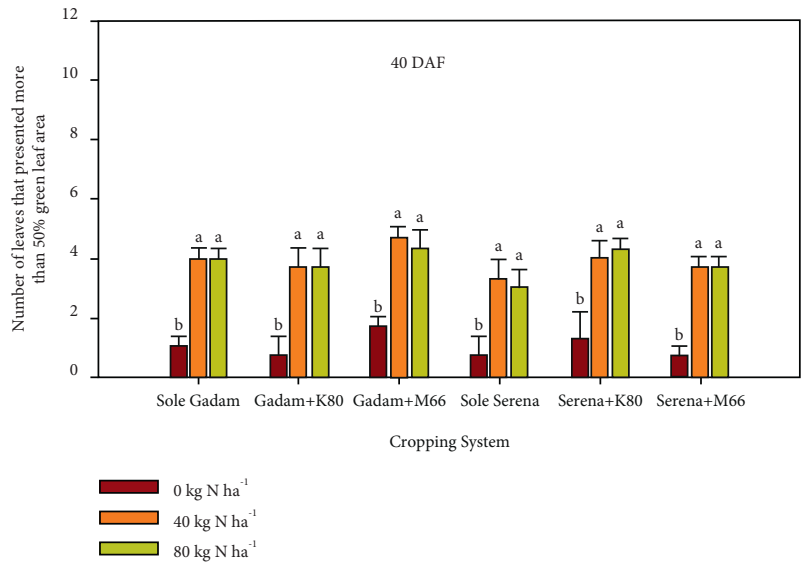

(f)

Figure 2: Continued. 


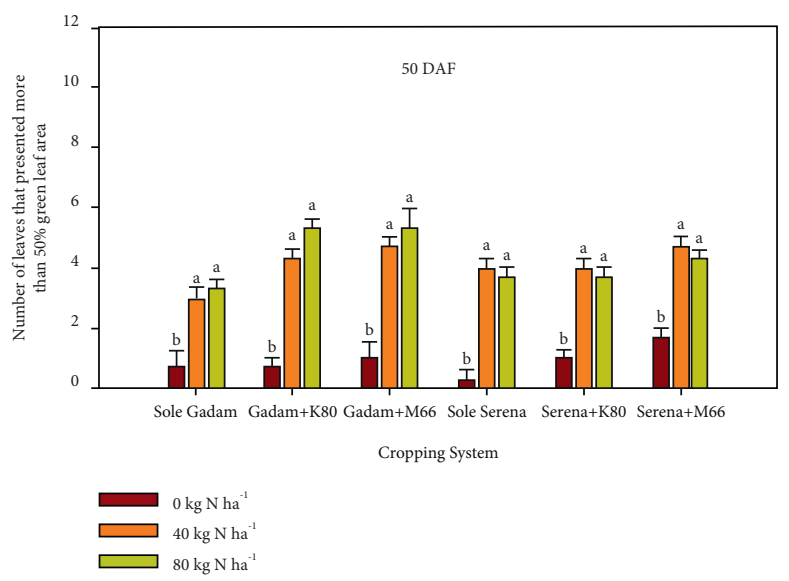

(g)

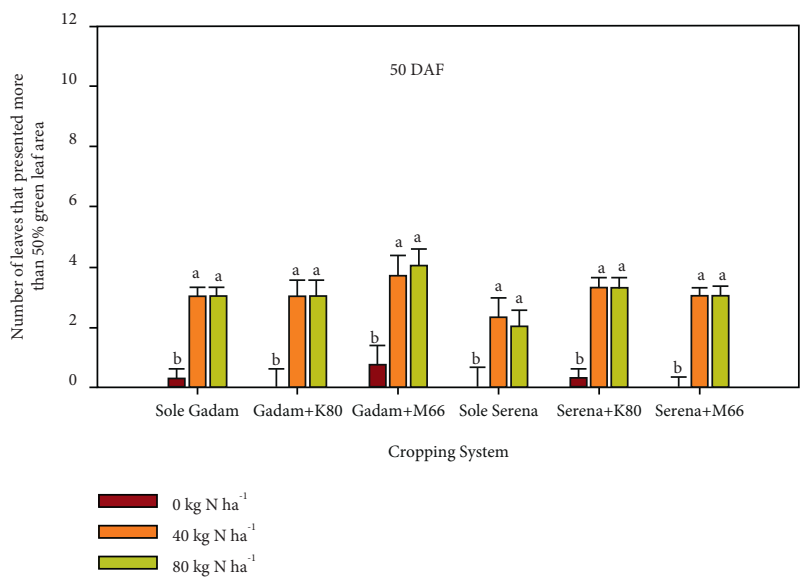

(h)

Figure 2: Number of leaves that presented more than $50 \%$ green leaf area at 10, 20, 40, and 50 days after flowering (DAF) of two sorghum varieties (Gadam and Serena) grown in sole and intercrop system with two varieties of cowpea (K80 and M66) and interactions with 0 , 40, and $80 \mathrm{~kg} \cdot \mathrm{N} \cdot \mathrm{ha}^{-1}$ at the KALRO research stations in Igoji (a, c, e, g) and Katumani (b, d, f, h) during 2018/2019 short rains season. Mean values followed by the same letter are not significantly different. The bars indicate the mean standard errors (SE).

across agroecologies and $\mathrm{N}$ rates under sorghum-cowpea intercropping since a significant variation in the cropping system $\times$ nitrogen interactions of the main effects was observed in the two experimental sites.

4.2. Leaf Senescence at the Whole-Plant Level. Like in other monocarpic plants, leaf senescence in sorghum is an agedependent developmental process [5, 7]. During grain filling, senescence is largely regulated by the source-sink relationship whereby nutrients are mobilized from leaves to the developing grain [33]. In support of the working hypothesis of the present study, intercropping significantly prolonged leaf greenness at the whole-plant level 0.2 leaves plant $^{-1}$ day $^{-1}$ compared with the sole crop. In a related study, there was a proso millet/mung bean intercropping system, intercropping delayed leaf senescence of proso millet where at least $10 \%$ more green leaves were recorded than counterparts under sole crop system [4].

On the other hand, the addition of $\mathrm{N}$ delayed leaf senescence by about 0.4 leaves plant ${ }^{-1}$ day $^{-1}$ potentially due to a balanced source-sink relationship in the fertilized crops but the present study did not establish the $\mathrm{N}$ nutritional status of the crops. Previous studies have shown that the addition improves $\mathrm{N}$ uptake efficiency and increases chloroplast size [34]. Thus, a lower demand for $\mathrm{N}$ in the fertilized crops might have delayed leaf senescence [35].

Despite some inconsistencies, cropping system$\times$ nitrogen interactions modulated leaf senescence in both experimental sites whereby the addition of $\mathrm{N}$ delayed leaf senescence in both sole and intercrop systems as shown by the higher number of leaves with over $50 \%$ green leaf area compared with control plots. Therefore, since leaf senescence is related to the photosynthetic capacity and chlorophyll content [3], the supply of $\mathrm{N}$ in the present study could have increased the photosynthetic apparatus and chlorophyll content in the plant leaves, hence, delaying leaf senescence. Similar results were reported in other C4 plants like sugarcane [36]. Further, under both sole and intercrop systems in fertilized plots, an increasing trend in senescence was observed as the crop matured which could have been attributed to a declining rate of photosynthesis and degradation of the chlorophyll in the leaves after flowering due to nutrient remobilization from senescing leaves to growing organs and seeds [37]. While this study was only limited to cropping system and nitrogen interactions, other potential interactions such as water $\times$ nitrogen not considered in the study could have potentially modulated geochemical cycling of nitrogen and leaf senescence as reported in previous study by Sadras [38]. Therefore, future studies should consider wider interactions to provide comprehensive analysis of factors that influence sorghum leaf senescence.

Further, our results suggest that the addition of $\mathrm{N}$ was more effective in delaying foliar senescence than intercropping senescence since senescence of 0.4 leaves plant ${ }^{-1}$ day $^{-1}$ was delayed with the addition of $N$ compared with 0.2 leaves plant ${ }^{-1}$ day $^{-1}$ due to intercropping. On the other hand, the lack of significant differences in yield between the addition of 40 and $80 \mathrm{~kg} \cdot \mathrm{N} / \mathrm{ha}$ suggests that sorghum grain yield can be maximized at lower $\mathrm{N}$ rates. However, further research is required to establish the economically optimum $\mathrm{N}$ rate in sorghum crop systems. The delay in leaf senescence at the whole-plant level due to intercropping might have been nonfunctional since sorghum grain yield attained in intercrop sorghum was significantly lower than counterparts in the sole cropping system. Hence, $N$ influence in prolonging leaf greenness at the whole-plant level and its modulation of grain yield was significantly large and could have superseded intercropping effect. The authors were cognizant that pathogen infection could influence leaf senescence as reported in an earlier study by Kitonyo [5]; hence, in the present study, pest and 


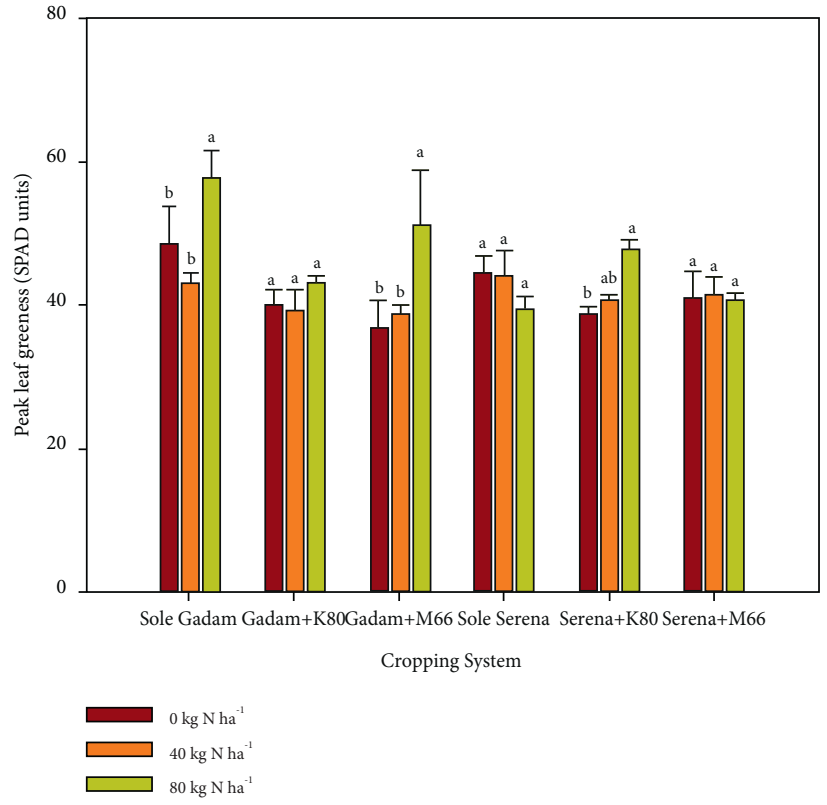

(a)

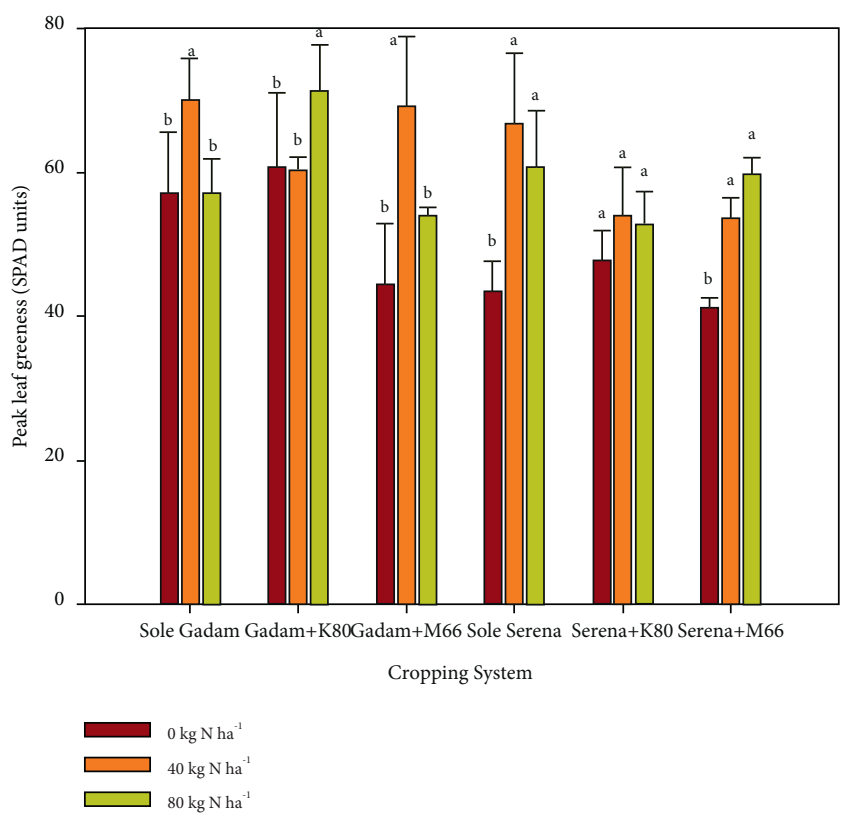

(b)

Figure 3: Peak leaf greenness (SPADmax) of two sorghum varieties (Gadam and Serena) grown in sole and intercrop system with two varieties of cowpea (K80 and M66) and interactions with 0, 40, and $80 \mathrm{~kg} \mathrm{~N} \mathrm{ha}^{-1}$ at the KALRO research stations in Igoji (a) and Katumani (b) during 2018/2019 short rains. Mean values followed by the same letter are not significantly different. The bars indicate the mean standard errors (SE).

diseases were timely controlled in all plots and their effect in influencing leaf greenness at the whole-plant level was minimized. However, environmental and genetic factors were beyond the scope of this study, which could have influenced leaf senescence and, hence, deserve more investigation.

4.3. Senescence of the Flag Leaf. In the present study, the traits of leaf senescence in sorghum, which comprised SPADmax, SPADmin, EC50, and rate of senescence were modulated by cropping system, $\mathrm{N}$ rate, and their interactions despite some inconsistencies. Intercropping reduced SPADmax by 8 units while $\mathrm{N}$ application improved this trait. This could be attributed to reduced intraspecies competition in sole compared with interspecies competition in intercropping systems for growth resources (nutrients, water, and light). These findings suggested that under the sole cropping system the progress of sorghum leaf senescence is delayed due to less competition for nutrients which increases photosynthetic capacity and improved electron transfer quantum efficiency of the photosystem II, hence, decreasing excess energy dissipation as heat [3].

Since SPAD reading measures the chlorophyll content in a plant leaf and is often associated with leaf greenness, the high SPADmax units recorded under the sole crop system suggest that the sole crop system is effective in improving stay-green traits in sorghum plants than the intercropping system. This could be explained by the slow degradation of chlorophyll due to the adequate presence of nutrients as competition effects are minimized under the sole crop system contributing to prolonged stay-green compared with an intercropping system. However, it should be noted that chlorophyll degradation may occur due to oxidative stress developed in chloroplasts, which is one of the main generators of reactive oxygen species (ROS) $[3,39]$; hence, the effect of antioxidant metabolism on senescence deserves investigation in future studies.

The presence of $\mathrm{N}$ had a large effect in driving the senescence traits especially peak leaf greenness (SPADmax) which could be attributed to the high production of chlorophyll and adequate supply of photosynthates in the leaves, hence, contributing to delayed leaf greenness. These results are consistent with a previous study on a similar C4 plant (maize) where nitrogen supply increased photosynthetic activity and delayed the leaf senescence [3, 5, 24]. Further, the interaction between the sole cropping system and $\mathrm{N}$ rate could have provided a conducive atmosphere for stay-green which is a reflection of delayed chlorophyll catabolism [40].

Like at the whole-plant level, cropping system $\times$ nitrogen interaction affected senescence of the flag leaf whereby senescence in sorghum under sole and intercrop system in $\mathrm{N}$-fertilized plots was delayed compared with unfertilized plots. This could be attributed to the external $\mathrm{N}$ supply which increased available $\mathrm{N}$ in the soil for plant use contributing to increased photosynthesis and slow degradation of chlorophyll hence slowing foliar senescence despite nutrient remobilization to reproductive organs $[37,41]$.

Maximum SPAD (peak leaf greenness) of the flag was significantly higher in Gadam sorghum variety than Serena by seven units and Gadam out-yielded Serena in both sites which further justifies the strong correlation between peak 
leaf greenness of the flag and grain yield. This could have been due to the variation in the genes that control leaf senescence processes in the two sorghum varieties as reported in an earlier study that genotypic variation greatly influenced stay-green expression in wheat [5]. This study, however, did not examine the mechanisms and genetic controls underlying the identified leaf senescence traits (SPADmax, EC50, SPADmin, and rate of senescence) which deserve to be investigated.

The addition of $\mathrm{N}$ increased the time to loss of $50 \%$ maximum SPAD (EC50) and rates of senescence. These results were possibly due to the significant impact of $\mathrm{N}$ in the development of chloroplast, which increased the chlorophyll content in the plant leaves contributing to staying green. This implied that $N$ enhanced "stay-green" phenotypic traits in sorghum and prolonged the leaf greenness causing a delayed $\mathrm{N}$ remobilization from the leaves (slow degradation of chlorophyll content) which helped prolonged photosynthetic capacity and therefore enhanced photosynthates (carbohydrate) supply to the sink organs (developing grain), consequently increasing the grain yield [7]. These results corroborate an earlier study that reported crops fertilized with fertilizer $\mathrm{N}$ had significantly higher leaf greenness compared to crops in control plots [6]. However, intercropping significantly reduced the rate of senescence by four SPAD units day ${ }^{-1}$ while EC50 was insensitive to the cropping system. These results suggest that maximum grain yields would be obtained in a sole cropping system and with the addition of $\mathrm{N}$ compared with an intercrop system and unfertilized plots since SPADmax and rate of senescence are functions of yield in a sole cropping system $[6,42]$.

\subsection{Sorghum Leaf Senescence and Modulation of Grain Yield.} The present study revealed that sorghum grain yield was profoundly modulated by leaf greenness (SPADmax and SPAD min) and faster rate of senescence as shown by the strong and positive correlation between grain yield and SPADmax, SPADmin, and rate of senescence. The former could have modulated grain yield by increasing the photosynthetic duration which resulted in high production of carbohydrates and sufficient supply of carbohydrates to the grain during the grain filling stage and consequently resulting in high grain yield while the latter might have modulated grain yield by increasing the remobilization of $\mathrm{N}$ from the senescing leaf to the developing grain which consequently results in high grain yield $[3,6,7,43]$. The positive correlation between the rate of senescence and grain yield was further explained in previous studies which reported that a rapid rate of grain filling was associated with a faster rate of senescence [9]. Further, Gong et al. [3] and Feller et al. [4] indicated that leaf area duration and green leaf area proportionally affected the grain yield in millet by regulating the source-sink relationship. Additionally, similar results were reported by Borrell et al. [44] and Jordan et al. [42] reporting that prolonged leaf greenness during grain filling was associated with yield when equilibrium was established between the supply of photosynthates and plant demand.

\section{Conclusions}

Sorghum-cowpea intercropping delayed leaf senescence at the whole plant but reduced leaf greenness of the flag leaf while $N$ delayed leaf senescence at both whole-plant and flag leaf scale. This implied that $\mathrm{N}$ was the main factor in driving leaf senescence at whole-plant and flag leaf level while the intercropping effect on senescence was generally nonfunctional at the whole-plant level and negatively affected senescence of the flag leaf. However, although intercropping reduced sorghum yield by about $50 \%$, cropping system (sole and intercrop) $\times \mathrm{N}$ rate modulated leaf greenness and grain yield suggesting that there is potential to exploit cropping system $\times N$ to improve stay-green traits and increase grain yield, especially in wetter environments than in areas with low rainfall. Further, while EC50 did not correlate with grain yield, faster rates of senescence, high SPADmax, and SPADmin units (leaf greenness) were associated with $\mathrm{N}$ supply and high sorghum grain yield under sole crop system but slower rate of senescence and lower units of SPADmax and SPADmin were associated with low grain yield. However, the effects of interspecies and intraspecies competition in sorghum-legume intercrop systems and source-sink relationships on the patterns of sorghum leaf senescence and its association with grain yield deserve further investigation across ecological zones.

\section{Data Availability}

The data used to support the study are available upon request.

\section{Conflicts of Interest}

The authors declare that they have no conflicts of interest in the publication of this article.

\section{Acknowledgments}

The authors would like to thank Borlaug Higher Education Agricultural Research and Development (BHEARD) for the funding support. Equally, the authors would like to thank the entire management of Kenya Agricultural and Livestock Research Organization (KALRO) of Embu and Katumani stations for availing land for setting the experiments of this study and providing support during the data collection. This material is based upon work supported by the United States Agency for International Development, as part of the Feed the Future initiative, under the CGIAR Fund, award number BFS-G-11-00002, and the predecessor fund the Food Security and Crisis Mitigation II grant, award number EEM-G-00-04-00013.

\section{Supplementary Materials}

The supplementary data contain results of soil analysis for Katumani experimental site (Table 1) and Igoji experimental site (Table 2) and Figure 1 illustrates the leaf senescence traits (SPADmax, SPADmin, EC50 and rate of senescence). (Supplementary Materials) 


\section{References}

[1] S. M. Karanja, A. M. Kibe, P. N. Karogo, and M. Mwangi, "Effects of intercrop population density and row orientation on growth and yields of sorghum-cowpea cropping systems in semi arid rongai, Kenya," Journal of Agricultural Science, vol. 6 , no. 5, pp. 34-43, 2014.

[2] B. Sibhatu and K. Belete, "Effect of cowpea density and nitrogen fertilizer on a sorghum-cowpea intercropping system in Kobo, northern Ethiopia," International Journal of Agriculture and Forestry, vol. 5, no. 6, pp. 305-317, 2015.

[3] X. W. Gong, C. J. LIU, U. Ferdinand et al., "Effect of intercropping on leaf senescence related to physiological metabolism in proso millet (Panicum miliaceum L.)," Photosynthetica, vol. 57, no. 4, pp. 993-1006, 2019.

[4] U. Feller, I. Anders, and T. Mae, "Rubiscolytics: fate of Rubisco after its enzymatic function in a cell is terminated," Journal of Experimental Botany, vol. 59, no. 7, pp. 1615-1624, 2008.

[5] J. T. Christopher, M. Veyradier, A. K. Borrell, G. Harvey, S. Fletcher, and K. Chenu, "Phenotyping novel stay-green traits to capture genetic variation in senescence dynamics," Functional Plant Biology, vol. 41, no. 11, Article ID 1035, 2014.

[6] O. M. Kitonyo, V. O. Sadras, Y. Zhou, and M. D. Denton, "Nitrogen supply and sink demand modulate the patterns of leaf senescence in maize," Field Crops Research, vol. 225, pp. 92-103, 2018.

[7] B. Kassahun, F. R. Bidinger, C. T. Hash, and M. S. Kuruvinashetti, "Stay-green expression in early generation sorghum [Sorghum bicolor (L.) Moench] QTL introgression lines," Euphytica, vol. 172, no. 3, pp. 351-362, 2010.

[8] O. M. Kitonyo, V. O. Sadras, Y. Zhou, and M. D. Denton, "Evaluation of historic Australian wheat varieties reveals increased grain yield and changes in senescence patterns but limited adaptation to tillage systems," Field Crops Research, vol. 206, pp. 65-73, 2017.

[9] Q. Xie, S. Mayes, and D. L. Sparkes, "Early anthesis and delayed but fast leaf senescence contribute to individual grain dry matter and water accumulation in wheat," Field Crops Research, vol. 187, pp. 24-34, 2016.

[10] J. M. Huho, "An analysis of rainfall characteristics in Machakos County, Kenya," IOSR Journal of Environmental Science, Toxicology and Food Technology, vol. 11, no. 4, pp. 64-72, 2017.

[11] K. Ram and R. Meena, "Evaluation of pearl millet and mungbean intercropping systems in arid region of Rajasthan (India)," Bangladesh Journal of Botany, vol. 43, no. 3, pp. 367-370, 2014.

[12] G. Corre-Hellou, J. Fustec, and Y. Crozat, "Interspecific competition for soil $\mathrm{N}$ and its interaction with $\mathrm{N} 2$ fixation, leaf expansion and crop growth in pea-barley intercrops," Plant and Soil, vol. 282, no. 1-2, pp. 195-208, 2006.

[13] T. Oseni and T. O. Oseni, "Evaluation of sorghum-cowpea intercrop productivity in savanna agro-ecology using competition indices hydroponics systems in vegetable crop production view project evaluation of sorghum-cowpea intercrop productivity in savanna agro-ecology using competition indices," Journal of Agricultural Science, vol. 2, no. 3, 2010.

[14] J. Layek, A. Das, T. Mitran et al., "Cereal+Legume intercropping: an option for improving productivity and sustaining soil health," Legumes for Soil Health and Sustainable Management, vol. 11, pp. 347-386, 2018.
[15] S. Ali, Y. Xu, Q. Jia et al., "Ridge-furrow mulched with plastic film improves the anti-oxidative defence system and photosynthesis in leaves of winter wheat under deficit irrigation," PLoS One, vol. 13, no. 7, Article ID e0200277, 2018.

[16] A. Das, R. Lal, D. P. Patel et al., "Effects of tillage and biomass on soil quality and productivity of lowland rice cultivation by small scale farmers in North Eastern India," Soil and Tillage Research, vol. 143, pp. 50-58, 2014.

[17] S. B. Luoni, F. H. Astigueta, S. Nicosia, S. Moschen, P. Fernandez, and R. Heinz, "Transcription factors associated with leaf senescence in crops," Plants, vol. 8, no. 10, pp. 1-28, 2019.

[18] A. García, M. Dorado, I. Pérez, and E. Montilla, "Effect of water deficit on the distribution of photoassimilates in rice plants (Orysa sativa L.)," Interciencia, vol. 35, no. 1, 2010.

[19] A. K. Biswal and A. Kohli, "Cereal flag leaf adaptations for grain yield under drought: knowledge status and gaps," Molecular Breeding, vol. 31, no. 4, pp. 749-766, 2013.

[20] K. Saitoh, K. Yonetani, T. Murota, and T. Kuroda, "Effects of flag leaves and panicles on light interception and canopy photosynthesis in high-yielding rice cultivars," Plant Production Science, vol. 5, no. 4, pp. 275-280, 2002.

[21] M. Ali, M. Hussain, M. Khan et al., "Sourcesink relationship between photosynthetic organs and grain yield attributes during grain filling stage in spring wheat (Triticum aestivum)," International Journal of Agriculture and Biology, vol. 12, pp. 509-515, 2010.

[22] R. Jebbouj and B. El Yousfi, "Barley yield losses due to defoliation of upper three leaves either healthy or infected at boot stage by Pyrenophora teres f. teres," European Journal of Plant Pathology, vol. 125, no. 2, pp. 303-315, 2009.

[23] K. Ji, Y. Wang, W. Sun et al., "Drought-responsive mechanisms in rice genotypes with contrasting drought tolerance during reproductive stage," Journal of Plant Physiology, vol. 169, no. 4, pp. 336-344, 2012.

[24] J. D. Lima, P. R. Mosquim, and F. M. Matta, "Leaf gas exchange and chlorophyll fluorescence parameters in Phaseolus vulgaris as affected by nitrogen and phosphorus deficiency," Photosynthetica, vol. 37, no. 1, pp. 113-121, 1999.

[25] R. Jaetzold and H. Schmidt, Farm Management Handbook of Kenya Vol. II C East Kenya. Natural Conditions and Farm Management Information, Kenya Ministry of Agriculture, GAT, GTZ, Nairobi, Kenya, 1983.

[26] J. Kinama, C. Ong, C. J. Stigter, J. Ng'ang'a, and F. Gichuki, "Hedgerow intercropping maize or cowpea/senna for drymatter production in semi-arid Eastern," Journal of Agricultural Science and Technology A, vol. 1, pp. 372-384, 2011.

[27] S. K. Shamme and C. V. Raghavaiah, "Sorghum (Sorghum bicolor L.) growth, productivity, nitrogen removal, n- use efficiencies and economics in relation to genotypes and nitrogen nutrition in Kellem- Wollega Zone of Ethiopia, East Africa," Advances in Crop Science and Technology, vol. 4, no. 3, pp. 3-10, 2016.

[28] D. R. Karanja, C. M. Githunguri, L. M'ragwa, D. Mulwa, and S. Mwiti, Variety Characteristics and Production Guidelines of Traditional Food Crops, KALRO Katumani and Eastern Province Horticulture and Traditional Food Crops Project, Kenya, 2006.

[29] A. A. Gomez and K. A. Gomez, Statistical Procedures for Agricultural Research, Vol. 6, A Wiley-Interscience Publication, Hoboken, NJ, USA, second edition, 1984.

[30] E. M. Musa, A. E. A. Elsheikh, I. A. M. Ahmed, and E. E. Babiker, "Intercropping sorghum (Sorghum bicolarL) and cowpea (Vignaunguiculata) effect of Bradyrhizobium 
inoculation and fertilization on mineral composition of sorghum seeds," ISRN Agronomy, vol. 35, pp. 61-83, 2012.

[31] A. O. Egesa, S. N. Njagi, and C. W. Muu, "Effect of facilitative interaction of sorghum-cowpea intercrop on sorghum growth rate and yields," Journal of Environmental and Agricultural Sciences, vol. 9, pp. 50-58, 2016.

[32] E. S. Jensen, G. Carlsson, and H. Hauggaard-Nielsen, "Intercropping of grain legumes and cereals improves the use of soil $\mathrm{N}$ resources and reduces the requirement for synthetic fertilizer N: a global-scale analysis," Agronomy for Sustainable Development, vol. 40, no. 1, p. 5, 2020.

[33] E. Gerardeaux, L. Jordan-Meille, J. Constantin, S. Pellerin, and M. Dingkuhn, "Changes in plant morphology and dry matter partitioning caused by potassium deficiency in Gossypium hirsutum (L.)," Environmental and Experimental Botany, vol. 67, no. 3, pp. 451-459, 2010.

[34] M. Li, B. Li, G. Guo et al., "Mapping a leaf senescence gene els1 by BSR-Seq in common wheat," The Crop Journal, vol. 6, no. 3, pp. 236-243, 2018.

[35] Y. He, H. Fukushige, D. F. Hildebrand, and S. Gan, "Evidence supporting a role of jasmonic acid in Arabidopsis leaf senescence," Plant Physiology, vol. 128, no. 3, pp. 876-884, 2002.

[36] D. Bassi, M. Menossi, and L. Mattiello, "Nitrogen supply influences photosynthesis establishment along the sugarcane leaf," Scientific Reports, vol. 8, no. 1, pp. 23-27, 2018.

[37] A. Maillard, S. DiquÃ@lou, V. Billard et al., "Leaf mineral nutrient remobilization during leaf senescence and modulation by nutrient deficiency," Frontiers of Plant Science, vol. 6, p. 317, 2015.

[38] V. O. Sadras, P. T. Hayman, D. Rodriguez et al., "Interactions between water and nitrogen in Australian cropping systems: physiological, agronomic, economic, breeding and modelling perspectives," Crop \& Pasture Science, vol. 67, no. 10, pp. 1019-1053, 2016.

[39] M. Djanaguiraman, J. Annie Sheeba, D. Durga Devi, and U. Bangarusamy, "Cotton leaf senescence can be delayed by nitrophenolate spray through enhanced antioxidant defence system," Journal of Agronomy and Crop Science, vol. 195, no. 3, pp. 213-224, 2009.

[40] H. Thomas and C. J. Howarth, "Five ways to stay green," Journal of Experimental Botany, vol. 51, pp. 329-337, 2000.

[41] P. Malagoli, P. Laine, L. Rossato, and A. Ourry, "Dynamics of nitrogen uptake and mobilization in field-grown winter oilseed rape (Brassica napus) from stem extension to harvest: I. Global $\mathrm{N}$ flows between vegetative and reproductive tissues in relation to leaf fall and their residual N," Annals of Botany, vol. 95, no. 5, pp. 853-861, 2005.

[42] D. R. Jordan, C. H. Hunt, A. W. Cruickshank, A. K. Borrell, and R. G. Henzell, "The relationship between the stay-green trait and grain yield in elite sorghum hybrids grown in a range of environments," Crop Science, vol. 52, no. 3, pp. 1153-1161, 2012.

[43] C. Masclaux-Daubresse, F. Daniel-Vedele, J. Dechorgnat, F. Chardon, L. Gaufichon, and A. Suzuki, "Nitrogen uptake, assimilation and remobilization in plants: challenges for sustainable and productive agriculture," Annals of Botany, vol. 105, no. 7, pp. 1141-1157, 2010.

[44] A. K. Borrell, J. E. Mullet, B. George-Jaeggli, E. J. van Oosterom, G. L. Hammer, and D. R. Klein, "Drought adaptation of stay-green sorghum is associated with canopy development, leaf anatomy, root growth, and water uptake," Journal of Experimental Botany, vol. 65, no. 21, pp. 6251-6263, 2014. 